\title{
23. THE SEDIMENTOLOGY OF SILT TURBIDITES FROM THE GULF OF ALASKA
}

\author{
David J. W. Piper, Department of Geology, Dalhousie University, Halifax, N. S., Canada
}

\begin{abstract}
Deep-water silt beds apparently deposited by turbidity currents are an important lithology in the Gulf of Alaska. Graded beds of moderately sorted silt of modal size 4 to $5 \phi$, often well laminated, may correspond to the Bouma $B$ and $C$ divisions in sand turbidites. Thick, poorly sorted, unlaminated silts with little grading may be equivalent to the $A$ division. Poorly sorted silts are also found in the $D$ division, perhaps as a result of rapid cohesive clay deposition. Some thin, well sorted, $6 \phi$ silts are found, which may be derived from turbidity currents formed by direct flow of sediment-laden, glacial outwash streams into the sea. Thin silt laminae are common, both singly and in groups. At least some were deposited by turbidity currents.

Turbidite and hemipelagic mud can sometimes be distinguished by the distribution of medium sand and coarser sediment of glacial erratic origin. In other cases, a hard fissile mud (?pelagic) overlies softer, darker, often coarser mud (?turbidite) which in turn overlies turbidite silt. Mud of turbidite origin appears to be an important sediment component.
\end{abstract}

\section{INTRODUCTION}

This paper describes deep-water silt beds found in the Gulf of Alaska on Leg 18 of the Deep Sea Drilling Project. Most are of Pleistocene age, but some date back to the Miocene. Figure 1 shows the location of DSDP Sites 177 to 181 , from which material was obtained. Detailed descriptions of the sites are to be found else where in this volume.

At these sites, beds are predominately of silt interbedded with mud. Sand beds are very rare. The sediment in the silt beds has a modal size of medium or coarse silt, and often contains 5 to 15 percent very fine sand. The beds are usually sharp based and graded; the modal size of sediment at the base of a few beds is within the very fine sand range.

The silt beds studies are believed to be turbidites, rather than the deposits of bottom currents, for the following reasons:

1) The overall rates of deposition are very high (up to $1800 \mathrm{~m} / \mathrm{my}$ ).

2) Derived shallow-water microfossils are common.

3) There are no clearly winnowed deposits, despite the abundance of poorly sorted glacial mud with erratic pebbles, granules and sand, which would produce a distinct deposit if winnowed. Neither is biogenous debris an important component of the silt beds, despite its abundance in some muds.

4) Many of the silt beds are graded, and have sharp bases.

5) There is evidence of rapid deposition and burial beneath the sediment surface. Some coccoliths are preserved below the carbonate compensation depth. Many beds are bioturbated only in their upper parts.

\section{EXPERIMENTAL PROCEDURES}

1. Visual observation of split cores and preparation of standard smear slides were employed. Detailed descriptions of typical cores are included in this paper.

2. X-radiography of 1- to 6-mm-thick slabs of indurated sediment was utilized. Kodak Crystallex film was used; exposure times were from 1 to 7 minutes, at $3 \mathrm{ma}$ and 25 to $40 \mathrm{kv}$.

3. Impregnations of wet samples were prepared by soaking them in a frequently replaced 50:50 mixture of acetone and methanol; then soaking in a 50:50 mixture of Araldite Ay18 and HZ18, diluted with an equal volume of the acetone-methanol mixture and a few drops of dibutyl phthalate. The acetone-methanol was allowed to evaporate slowly, and the sample then cured over a period of days gradually raising the temperature to $150^{\circ} \mathrm{C}$. Some indurated samples were dried and impregnated with Canada balsam. Mr. M. Badcock prepared thin sections from the impregnations.

4. An E.E.L. photoextinction sedimentometer was used to determine the grain size of carefully selected small samples. Over 100 analyses were made. The theory of the method is described by Simmons (1959). The instrument used was similar in design to that of Jordan et al. (1971), but with a fall distance of $6.4 \mathrm{~cm}$. and without rangechanging facilities on the galvonometer. Samples were treated with hydrogen peroxide (and where necessary in an ultrasonic bath) to disaggregate. They were wet sieved at 63 microns, and the sand fraction dried and weighed. The lutum was diluted sufficiently to by analysed. Calgon ( $0.1 \%$ solution) was used throughout as a dispersing agent. It was realised after most of the analyses had been run that with 


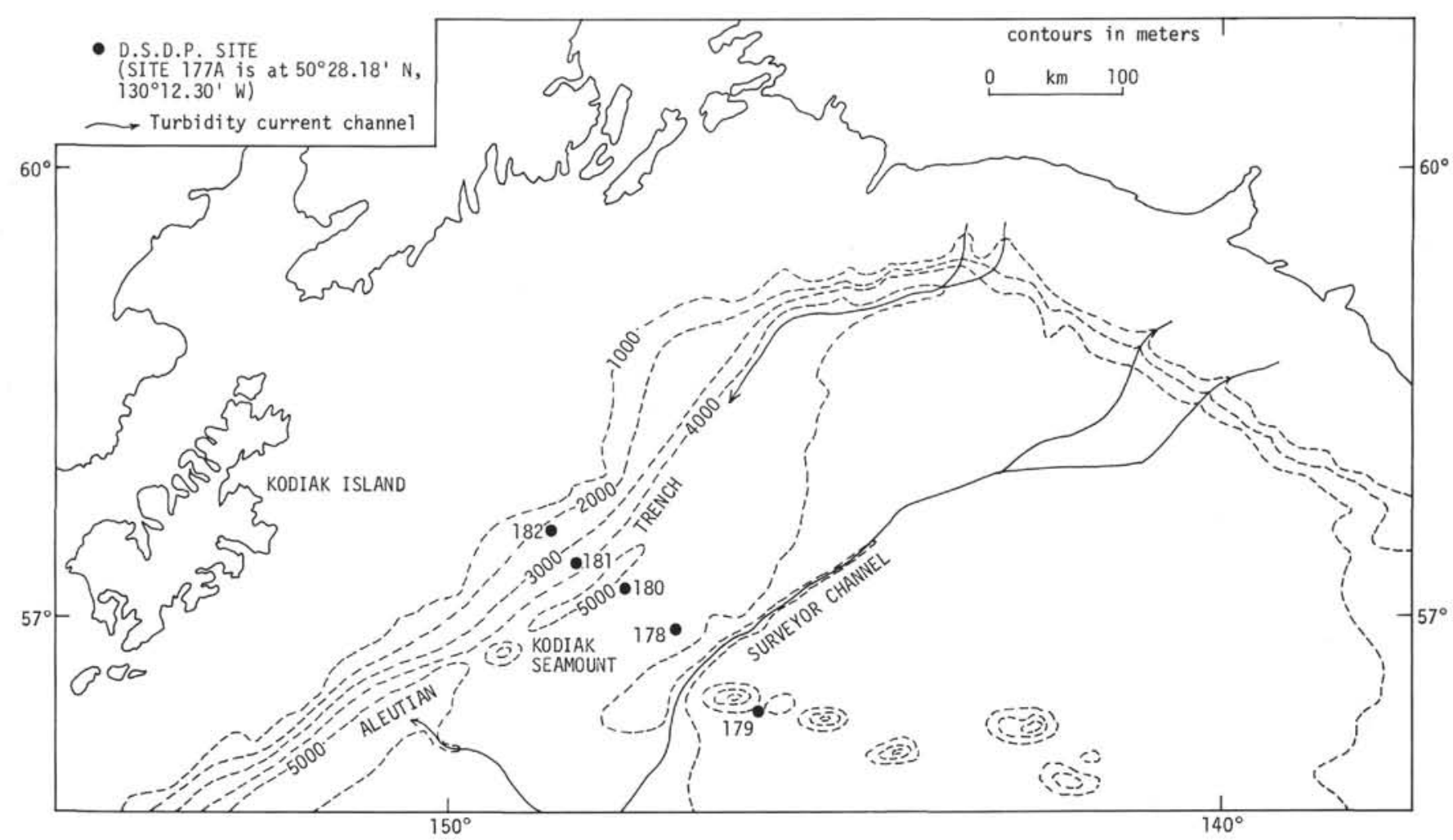

Figure 1. Bathymetry of the NE Gulf of Alaska, showing location of DSDP sites.

the small amount of sediment used, this was too high a concentration of Calgon for maximum dispersion. The fine clay fraction was probably not well dispersed. Analyses are thus internally consistent, but not directly comparable to other DSDP pipette analyses. Computer reduction of the data was carried out at the University Computing Laboratory, Cambridge. The cumulative frequency plots presented have been smoothed to remove major inconsistent deviations probably resulting from voltage fluctuations. Details within the 4 to $5 \phi$ range should be treated with skepticism.

5 . The results of some standard DSDP grain-size and carbon-carbonate analyses have been incorporated in this study.

6. The terminology of Folk (1966) has been used for describing sorting.

7. The term mud was used on board ship to describe any silt-clay mixture, with fine mud referring to clays with a small amount of silt, and coarse mud to silts with a small amount of clay. These shipboard descriptions have been retained. Subsequently, DSDP advised use of the terms silty clay and clayey silt, replacing mud. These terms have been used in laboratory descriptions. Mud has still been used as a general term including silty clay and clayey silt.

\section{PRINCIPAL TYPES OF SILT BEDS}

Several different types of silt beds have been distinguished, and may be classified as follows:

1) Moderately sorted, usually thin-bedded silts (from Sites 178 and 180 ).

2) Thick-bedded, unlaminated (massive), poorly sorted silts (from Sites 178 and 181).
3) Well-sorted fine silts (from the Miocene of Site 178).

4) Poorly sorted, indurated silts overlying sands (from the lower part of Hole 177A).

5) Grouped silt laminae (studied mainly from Sites 178 and 180 , but found at other sites).

6) Isolated silt laminae (found in Holes 177A, 178, 180 and 181).

\section{Moderately Sorted, Usually Thin-Bedded, Silts}

Moderately sorted silts, in beds typically 1 to $5 \mathrm{~cm}$ thick, are characteristic of Site 180 and upper part of Site 178 (Figure 2). Thicker, moderately sorted silt beds, up to $40 \mathrm{~cm}$ thick, are also found at Site 180 , but do not otherwise differ from the commoner thinner beds.

Beds are sharp based, and also often have quite sharp tops, and then pass up into mud. The samples are insufficiently indurated to show internal structure, except for a 3-cm-thick silt bed in Section 178-17-2, which is cemented by calcium carbonate and shows cross lamination at the base of the bed passing up into parallel lamination (Plate 1).

Photoextinction sedimentometer determinations of grain size are shown in Figure 3. The silts are moderately sorted, with a median size of around $5 \phi$. There are few detailed analyses demonstrating grading in thin beds. One thin bed at $178-27-1(81)$ is coarser at the base than at the top. Two thick beds ( 10 and $24 \mathrm{~cm}$ thick) from Site 180 are graded; a third ( $65 \mathrm{~cm}$ thick) is of constant grain size through the five samples analysed. Table 1 shows the ranking of smear slide sequences by grain size, and shows that most of the beds are graded. 

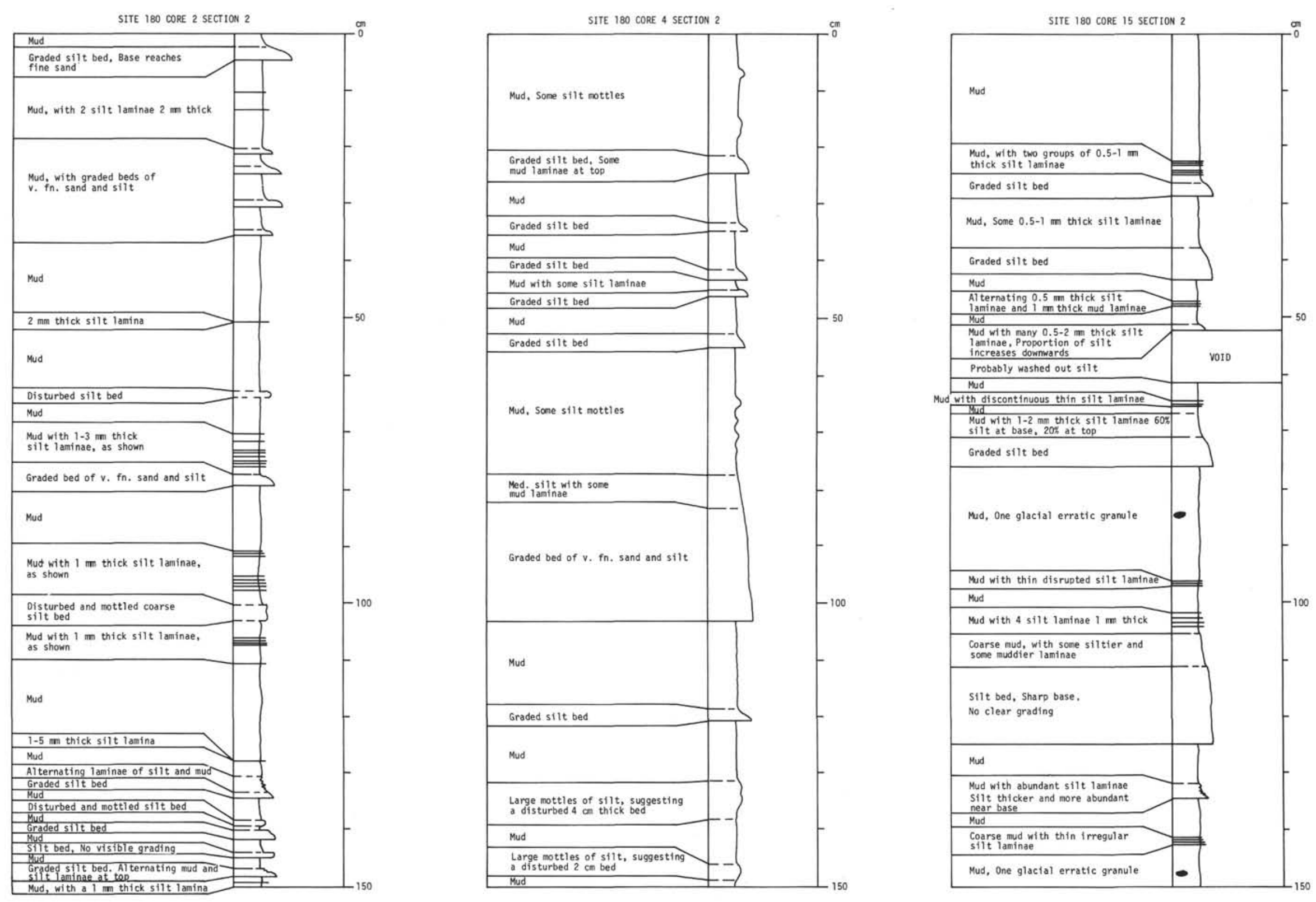

Figure 2. Detailed lithologic descriptions of sections with moderately sorted, usually thin-bedded, silts from Site 180. Width of vertical column proportional to grain size. Disturbed beds, where recorded, are believed to be bioturbated, rather than disturbed during coring. 

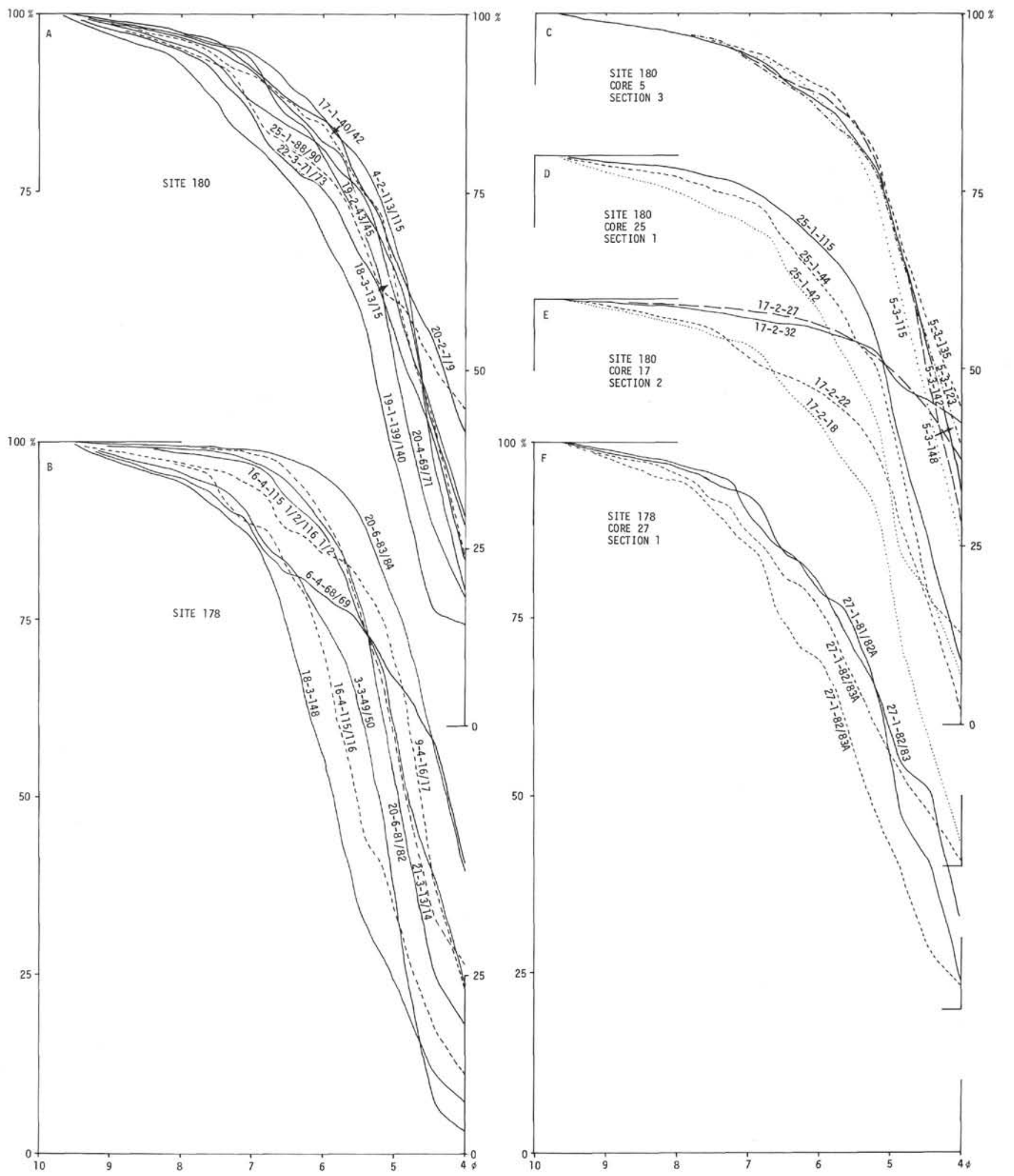

Figure 3. Grain size distribution in moderately sorted, usually thin-bedded, silts from Sites 178 (B and F) and 180 (A, C-E), as determined by photoextinction sedimentometer. Determinations at different levels in four individual beds shown in $\mathrm{C}-\mathrm{F}$ (full line indicates lowest determination in bed, dotted line the highest). 
TABLE 1

Visual Ranking of Smear Slides by Grain Size ${ }^{a}$

\begin{tabular}{|c|c|c|c|c|c|c|c|c|c|c|c|c|c|c|c|c|c|c|c|c|}
\hline & \multicolumn{10}{|c|}{ Moderately sorted, usually thin-bedded silts } & \multicolumn{5}{|c|}{$\begin{array}{l}\text { Thick-bedded, unlaminated, } \\
\text { poorly-sorted silts }\end{array}$} & \multirow[b]{2}{*}{ 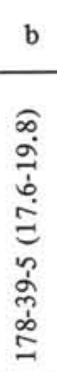 } & \multirow[b]{2}{*}{ 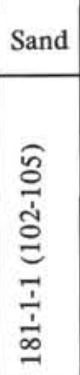 } & \multicolumn{3}{|c|}{ Silt } \\
\hline 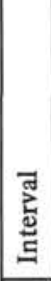 & 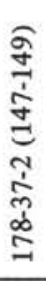 & 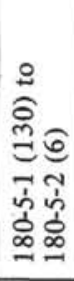 & 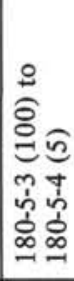 & 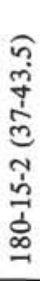 & 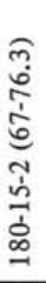 & 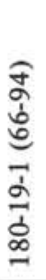 & 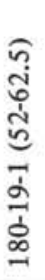 & 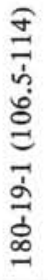 & 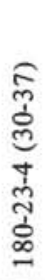 & 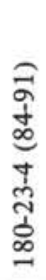 & 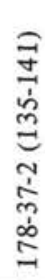 & 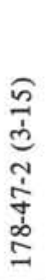 & 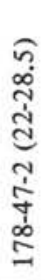 & 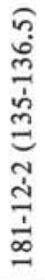 & 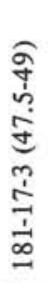 & & & 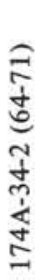 & 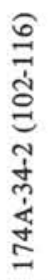 & 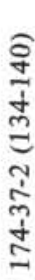 \\
\hline $\mathscr{\mathscr { H }}$ & $\begin{array}{l}3 \\
2 \\
1\end{array}$ & $\begin{array}{l}7 \\
6 \\
5 \\
4 \\
2 \\
1 \\
3\end{array}$ & $\begin{array}{l}8 \\
6 \\
3 \\
2 \\
7 \\
1 \\
4 \\
5\end{array}$ & $\begin{array}{l}4 \\
3 \\
2 \\
1\end{array}$ & $\begin{array}{l}6 \\
4 \\
5 \\
3 \\
2 \\
1\end{array}$ & $\begin{array}{l}6 \\
4 \\
5 \\
3 \\
2 \\
1\end{array}$ & $\begin{array}{l}5 \\
4 \\
2 \\
3 \\
1\end{array}$ & $\begin{array}{l}5 \\
4 \\
3 \\
2 \\
1\end{array}$ & $\begin{array}{l}3 \\
1 \\
4 \\
2\end{array}$ & $\begin{array}{l}5 \\
4 \\
2 \\
3 \\
1\end{array}$ & $\begin{array}{l}5 \\
3 \\
2 \\
1 \\
4\end{array}$ & $\begin{array}{l}3 \\
2 \\
1\end{array}$ & $\begin{array}{l}5 \\
4 \\
3 \\
2 \\
1\end{array}$ & $\begin{array}{l}2 \\
1 \\
3 \\
4\end{array}$ & $\begin{array}{l}4 \\
1 \\
3 \\
2\end{array}$ & $\begin{array}{l}4 \\
3 \\
2 \\
1\end{array}$ & $\begin{array}{l}5 \\
4 \\
3 \\
1 \\
2\end{array}$ & $\begin{array}{l}4 \\
2 \\
3 \\
1\end{array}$ & $\begin{array}{l}4 \\
3 \\
2 \\
1\end{array}$ & $\begin{array}{l}6 \\
5 \\
3 \\
2 \\
4 \\
1\end{array}$ \\
\hline
\end{tabular}

${ }^{a}$ Series of smear slides at approximately equal intervals through an individual bed have been ranked according to the mean grain size of the silt. In the columns, 1 refers to the slide with the coarsest grain size, 2 with the next finer, and so on. The highest number refers to the finest grain size in the bed. The numbers are arranged in order according to the position of the smear slide in the bed. Thus a sequence 54321 indicates perfect grading.

${ }^{b}$ Well-sorted, fine silt.

Petrographic determinations are shown in Table 2. Mica is generally an inimportant constituent of the silts. Several silts from Site 178 show a distinct enrichment in hornblende at the extreme base of the bed; the reason for this is uncertain.

\section{Thick-Bedded, Unlaminated, Poorly Sorted Silts}

In the unit from 270 to 742 meters at Site 178 , silt beds from a few to $55 \mathrm{~cm}$ thick are found (Figure 4). They are usually poorly sorted. Most of the beds have sharp bases, and some grade upwards into mud. They are characterised by an apparent absence of lamination. Two similar beds, cemented by calcium carbonate, are found in Sections 48-1 and 51-1; although one of these beds analysed by Hayes (Chapter 29, this volume) is not so poorly sorted. No lamination was seen either in these beds or in partially indurated beds. Pebble-sized mud clasts were found in Section 43-1 and smaller mud clasts in Section 33-4. The cemented bed in Section 48-1 contains dispersed mud and wood clasts (Plate 1).

Photoextinction sedimentometer determinations of grain size are shown in Figure 5. Note that the sorting is generally poor, but is variable. Initial visual description of the cores suggested that many of the beds are graded. This is only partially confirmed by subsequent analysis. The sharp base of the beds, and the upward passage into mud, give the impression of grading.

A series of samples from Section 47-1 through two silt beds show almost constant grain size within individual beds, but considerable difference between the two beds.

A very thick bed in Section 43-1 has coarsest sediment at the base of the bed, and finest at the top, but no regular grading within the bed.

Similar beds are common at Site 181. Size analyses from four different beds, ranging from 10 to $140 \mathrm{~cm}$ thick, are
TABLE 2

Petrography of Selected Silts

\begin{tabular}{|c|c|c|c|c|c|c|c|}
\hline Sample & $\begin{array}{l}\text { 를 } \\
\text { 己ै }\end{array}$ & 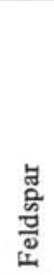 & 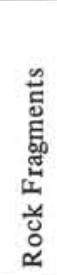 & 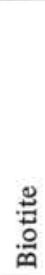 & 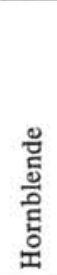 & 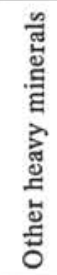 & 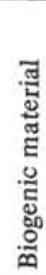 \\
\hline $178-37-2(137)$ & 44 & 24 & 2 & 4 & 10 & 8 & 8 \\
\hline $178-37-2(143)$ & 58 & 26 & 2 & 2 & 4 & 8 & 2 \\
\hline $178-47-2(15)$ & 61 & 21 & 4 & 6 & 4 & 4 & 0 \\
\hline $178-47-2(27)$ & 62 & 26 & 4 & 8 & 0 & 0 & 0 \\
\hline $180-5-1(140)$ & 48 & 15 & 4 & 2 & 19 & 12 & 0 \\
\hline $180-5-2(6)$ & 46 & 22 & 10 & 2 & 10 & 10 & 0 \\
\hline $180-23-4(37)$ & 52 & 18 & 8 & 0 & 14 & 8 & 0 \\
\hline $180-23-4(89.5)$ & 54 & 14 & 6 & 0 & 26 & 0 & 0 \\
\hline
\end{tabular}

Percentage composition based on counts of at least 50 grains in smear slides.

also shown in Figure 5. Mud clasts were observed in the bed in Section 3-4. Although beds have sharp bases, and pass into mud at the top, they are not graded internally.

In some samples (most prominently in 181-9-3(25) and 181-9-3(60) - see Figure 5), there is a pronounced bimodal size distribution, with a lack of grains in the 5 to $6.5 \phi$ range.

\section{Well-Sorted, Fine Silts}

From 392 to 399 meters at Site 178 (Core 39), there is an unusual occurrence of alternating thin beds of olive gray fine silt and medium dark gray mud (Figure 6). The silt layers are from 2 to over $20 \mathrm{~mm}$ thick, and are composed dominantly of quartz, with some carbonate. Their modal 

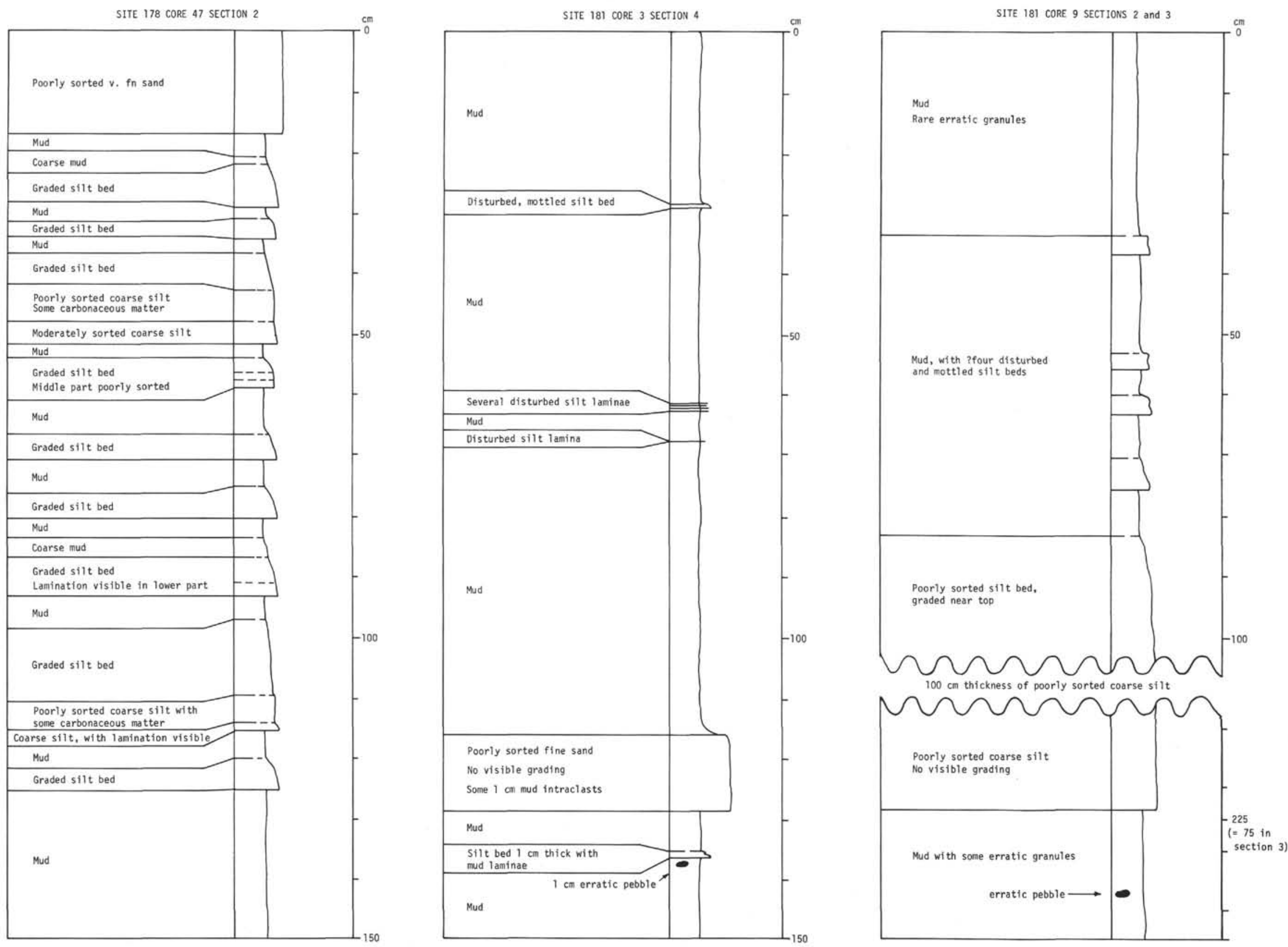

Figure 4. Detailed lithologic descriptions of sections with thick-bedded, unlaminated, poorly sorted silts and fine sands, from Sites 178 and 181 (for explanation and key, see Figure 2). 
TABLE 3

Size Distribution Determined by Pipette Analysis for Selected Silts and Muds ${ }^{\mathrm{a}}$

\begin{tabular}{l|ccrrrrrrrc}
\hline & \multicolumn{10}{c}{ Per Cent Coarser Than } \\
\cline { 2 - 10 } \multicolumn{1}{c}{ Sample } & $1 \phi$ & $2 \phi$ & $3 \phi$ & $4 \phi$ & $5 \phi$ & $6 \phi$ & $7 \phi$ & $8 \phi$ & $9 \phi$ & $10 \phi$ \\
\hline $180-12-1(120-122)$ & 0.60 & 3.07 & 5.62 & 6.0 & 43.9 & 71.6 & 81.3 & 85.2 & 88.8 & 90.9 \\
$180-12-1(146-148)$ & 0.00 & 0.10 & 0.90 & 12.5 & 58.4 & 78.8 & 86.7 & 89.8 & 92.4 & 93.9 \\
$181-4-4(17-18)$ & 0.00 & 0.00 & 0.00 & 0.2 & 17.9 & 44.4 & 61.5 & 68.4 & 75.3 & 81.1 \\
$181-6-3(30-32)$ & 0.00 & 0.00 & 0.00 & 0.0 & 0.5 & 9.4 & 25.1 & 38.7 & 52.0 & 65.1 \\
$181-9-2(106-108) \mathrm{b}$ & 0.00 & 0.00 & 6.70 & 26.6 & 56.7 & 67.5 & 74.3 & 78.6 & 83.2 & 86.9 \\
$181-9-3(27-29)^{\mathrm{b}}$ & 0.00 & 0.80 & 40.00 & 67.1 & 71.4 & 75.4 & 79.4 & 82.1 & 85.9 & 89.4 \\
$181-17-6(30-32)$ & 0.00 & 0.00 & 0.0 & 0.0 & 0.0 & 25.9 & 50.8 & 62.3 & 70.8 & 77.5 \\
\hline
\end{tabular}

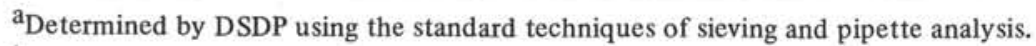

bAnalyses 181-9-2 (106-108) and 181-9-3 (27-29), c.f. Figures 4 and 5E.

size is 6 to $7 \phi$, and they are well sorted. Photoextinction sedimentometer size analyses are shown in Figure 7.

A thin section of a silt bed about $1 \mathrm{~cm}$ thick shows the bed to be laminated, with some of the individual laminae graded. There is a distinct grading (from 5.7 to $6.7 \phi$ ) through the bed. Both base and top are sharp.

A little way below the lowest such silt in Section 178-39-5, there is a 4-cm-thick ash bed in diatomite. This has no apparent relationship to the silts.

\section{Indurated Silts}

Indurated silts are common in the lower part of Hole 177A. They generally overlie a few centimeters of wellsorted laminated or cross-laminated fine or very fine sand, generally much less lithified. Most of the silts appear to pass up into mud (Figure 8). Visual examination and X-radiographs (Plate 1) show most of the silts are well laminated, and reveal little bioturbation. They probably correspond to the $D$ division of the Bouma sequence in turbidites.

Thin sections show the sediment to be very poorly sorted, usually without prominent lamination being visible even where the X-radiographs show lamination. Elongate grains are oriented parallel to bedding, and only in a few places is an alternation of well-sorted and poorly sorted laminae visible. Grading is very indistinct. The poor sorting and indistinct grading are confirmed by photoextinction sedimentometer size analyses (Figure 9).

\section{Grouped Silt Laminae}

Thin silt laminae in mud are common in several holes (Figure 10). Many such laminae are single, but some are clearly grouped. Beds of these grouped laminae often contain unusually coarse mud and abruptly overlie normal fine mud. In some cases, well-sorted ("clean") silts alternate with silts with poorer sorting and a higher clay content ("dirty"). A number of such groups of laminae were impregnated and thin sectioned.

Figure 11a shows a typical thin section of such a bed consisting of a group of silt laminae. The lowest lamina has a sharp base on silty clay, and consists of well-packed silt. It grades up into clayey silt, with both an increase in the proportion of clay and a decrease in the size of silt grains. Some of the overlying laminae are similar; others have less pronounced grading and a sharp top. Many of the silt laminae are separated by silty clay laminae. The proportion of silt in the silty clay laminae decreases higher in the bed.
Some of the lower silt laminae are lenticular. The silt laminae become thinner and less abundant in the upper part of the bed. Most individual silt laminae have sharp bases.

Figure 12 is a representation of the distribution of silt in the bed. The mean diameter of all silt grains coarser than $7 \phi$ have been plotted against their height above the base of the bed, for a $0.5 \mathrm{~mm}$ wide strip of thin section. (For details of the technique used, see Piper, 1972). Two well-sorted silt laminae have not been digitised.

In this plot, the distance along the $x$-axis indicates the size of silt grains, while the density of points is an indication of packing or sorting.

The contrast between well-sorted and poorly sorted clayey silt laminae is visible, as is the grading within individual silt laminae. There is no clear variation in the grain size of the coarse bases of silt laminae in the lower part of the bed, but higher up, silt coarser than $5.5 \phi$ is not found above $2 \mathrm{~mm}$ from the base of the bed. At least in the upper part of this bed there is a distinct grading, an upward decrease in the grain size of the larger silt grains and in the abundance of silt laminae.

Figure $11 \mathrm{~b}$ shows a different type of bed. At the base is a muddy sand $(a)$, with grains up to medium sand size. This is followed $(b)$ by alternating laminae of silty clay and clayey silt, with sand grains scattered throughout. At the top, the clayey silt laminae become better sorted, and eventually a well-sorted medium silt $(c)$ is found. There are no sand grains above this, but some diffuse silty laminae occur. Through this bed, there is an upward decrease in size and abundance of sand grains.

Figure $11 \mathrm{c}$ superficially resembles Figure $11 \mathrm{a}$. There are a series of sharp-based silt laminae, with the lower laminae coarser than the higher ones (with the exception of one lamina (b), which is as coarse as the base of the bed), and with silt laminae eventually disappearing passing up through the bed. Silty clay occurs between the silt laminae. One lamina $(c)$ has a sharp-edged protuberance at its base. This looks more like a filled burrow than a load cast. Some of the thinner laminae are discontinuous, which may be primary, or due to bioturbation.

The lithology below the lowest prominent sharp-based silt lamina is a clayey silt; in other words, it has more silt than the lithology between the silt laminae. In its upper part, just below the lowest sharp-based silt lamina $(a)$, are two clay-rich silt laminae, with gradational bases and tops ( $d$ and $e$ ). Lamina $e$ is less well sorted and finer than lamina $d$, which is in turn less well sorted and finer than $a$. 

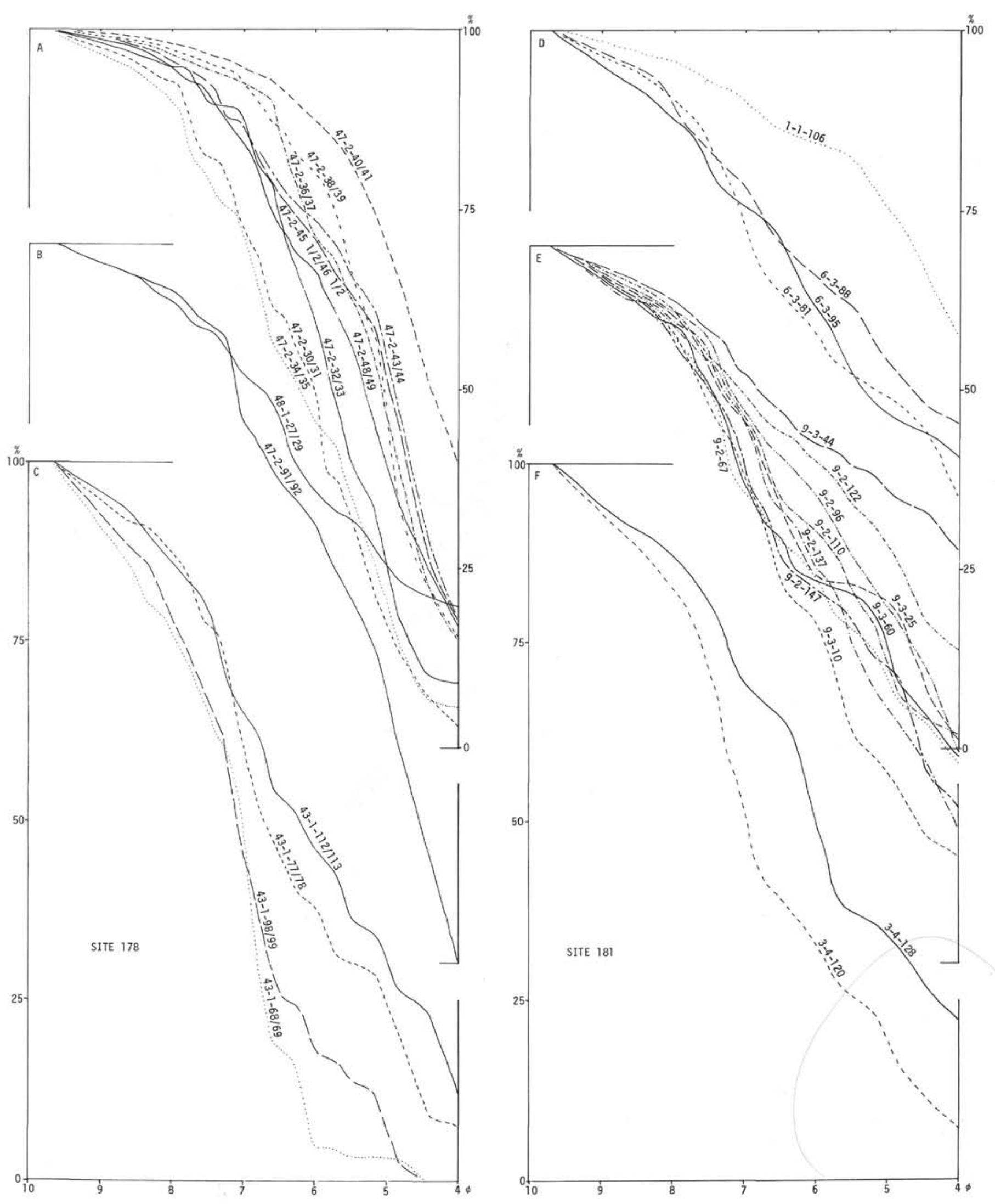

Figure 5. Grain size distribution in thick-bedded unlaminated, poorly sorted silts, Sites 178 (A-C) and 181 (D-F), as determined by photoextinction sedimentometer. Determinations at different levels in individual beds shown in A 12 beds $30-33$ $\mathrm{cm}$ and $37-51 \mathrm{~cm}$, see Figure 4), C, D, E and F (full line indicates lowest determination in bed, dotted line is the highest). 


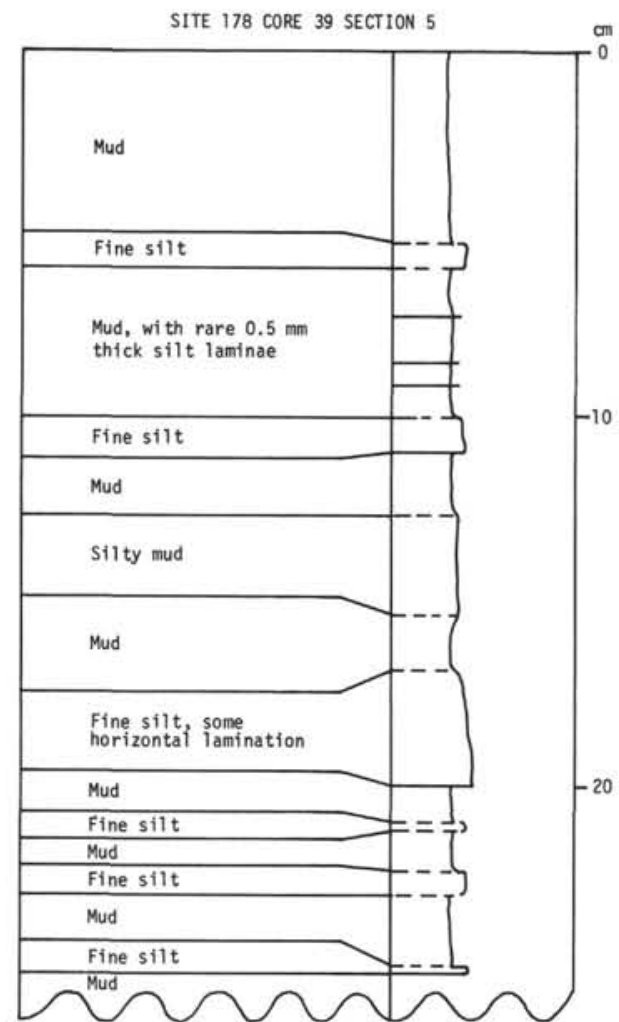

$35 \mathrm{~cm}$ not shown

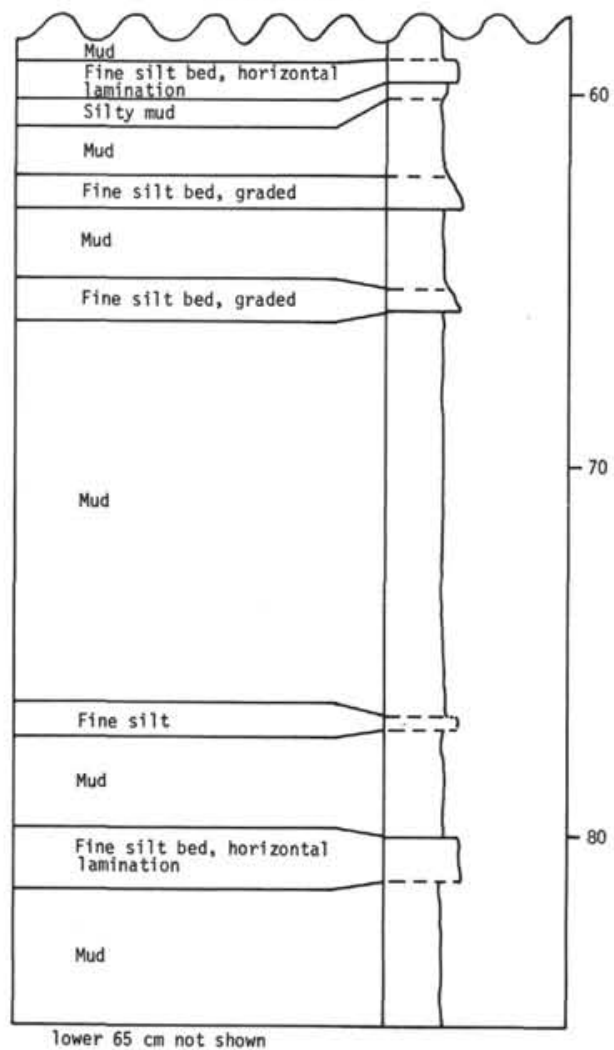

Figure 6. Detailed lithologic description of section with well-sorted, fine silt beds, Site 178, Core 39. (Horizontal scale as in Figure 2; note that vertical scale is different).

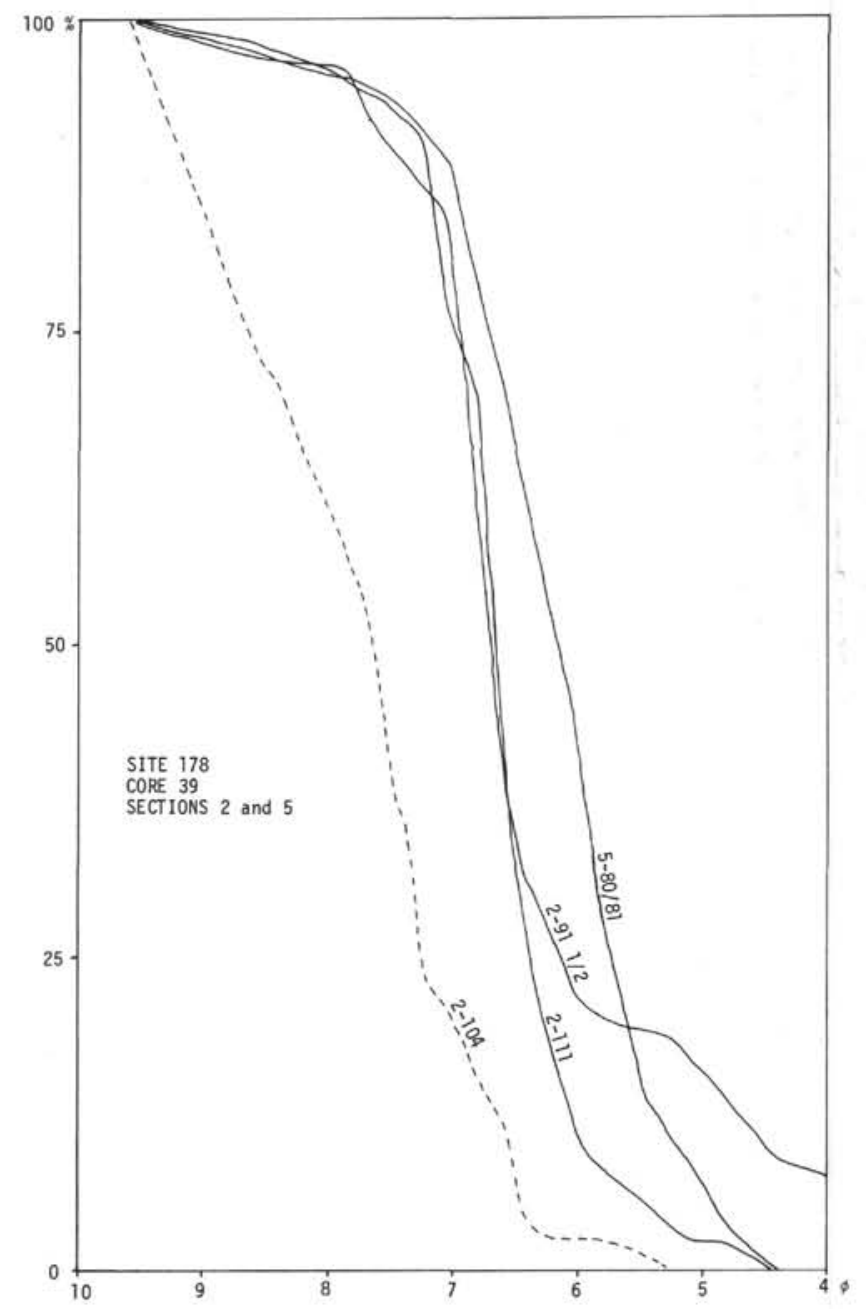

Figure 7. Grain size distribution in three silts and one mud from Site 178, Core 39. Determined by photoextinction sedimentometer.

Figure 13 shows sketches of split cores from which series of smear slides were taken. Figures $13 \mathrm{a}$ and $13 \mathrm{~b}$ resemble Figure $11 \mathrm{~b}$ in having poorly sorted sediment with sand grains at the base of the bed. Figures $13 \mathrm{c}$ and $13 \mathrm{~d}$ are more like Figure $11 \mathrm{a}$, with only clean silts present. These two types of grouped silt laminae appear to be common.

Regrettably, at this time, no photoextinction sedimentometer analyses are available of sediments from these beds of grouped silt laminae.

The dominant feature of the beds described is some sort of grading (an upward decrease in size and abundance of coarser grains), with a lamination superimposed on this pattern. Piper (1972) described in greater detail similar beds from lithified rocks, and suggested that only turbidity currents could explain frequently occurring graded beds. He argued that a steadily waning bottom current could produce a graded bed similar to a turbidite; but that steadily waning bottom currents were unlikely to occur. This assumption is perhaps false. Tide-related bottom currents may show a gradual waning (Shepard and Marshall, 1969), which could produce an upward decrease in grain 


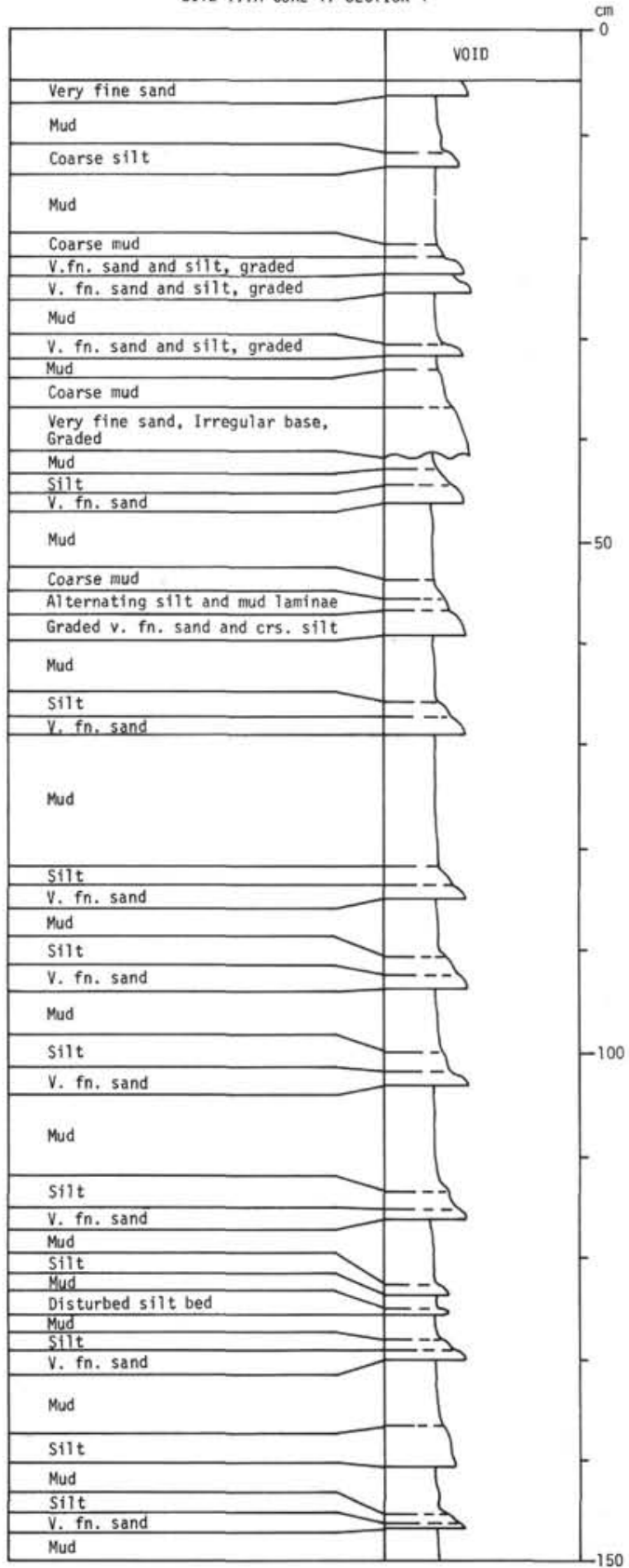

SITE $177 \mathrm{~A}$ CORE 18 SECTION 3

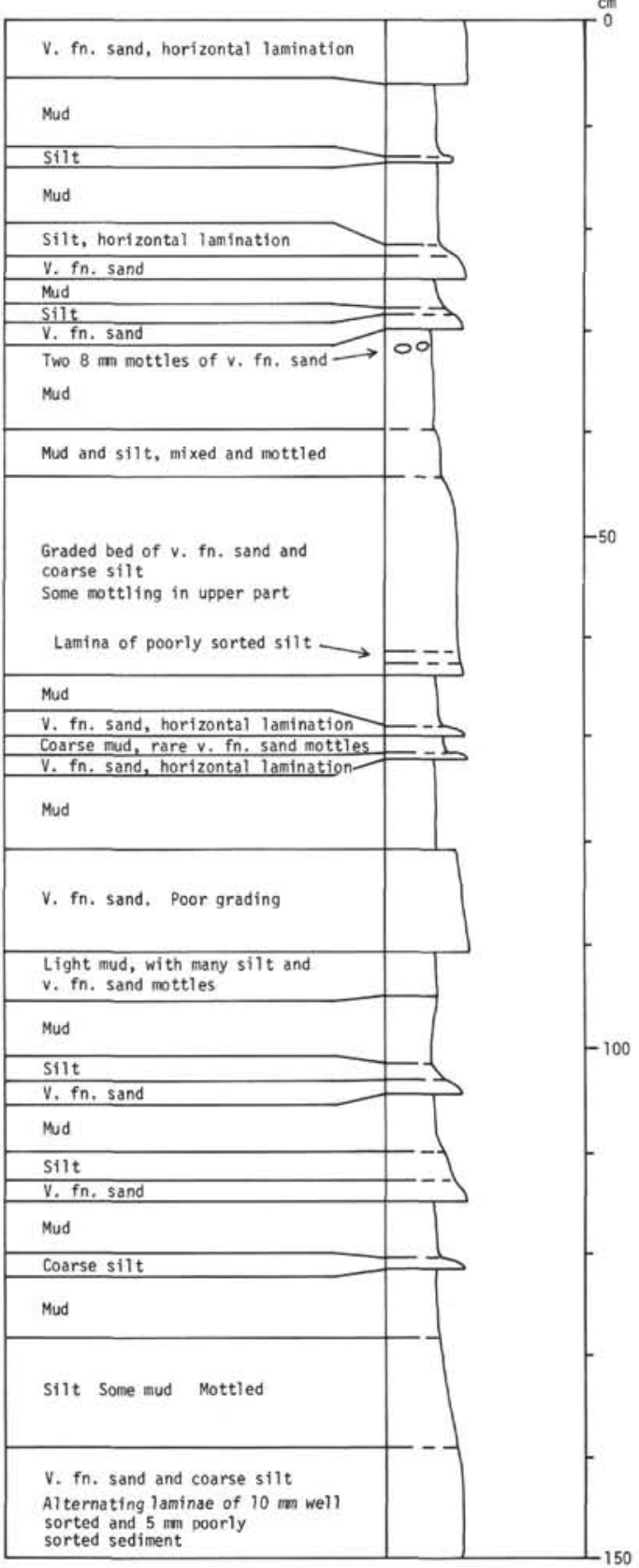

SITE 177A CORE 24 SECTION 4

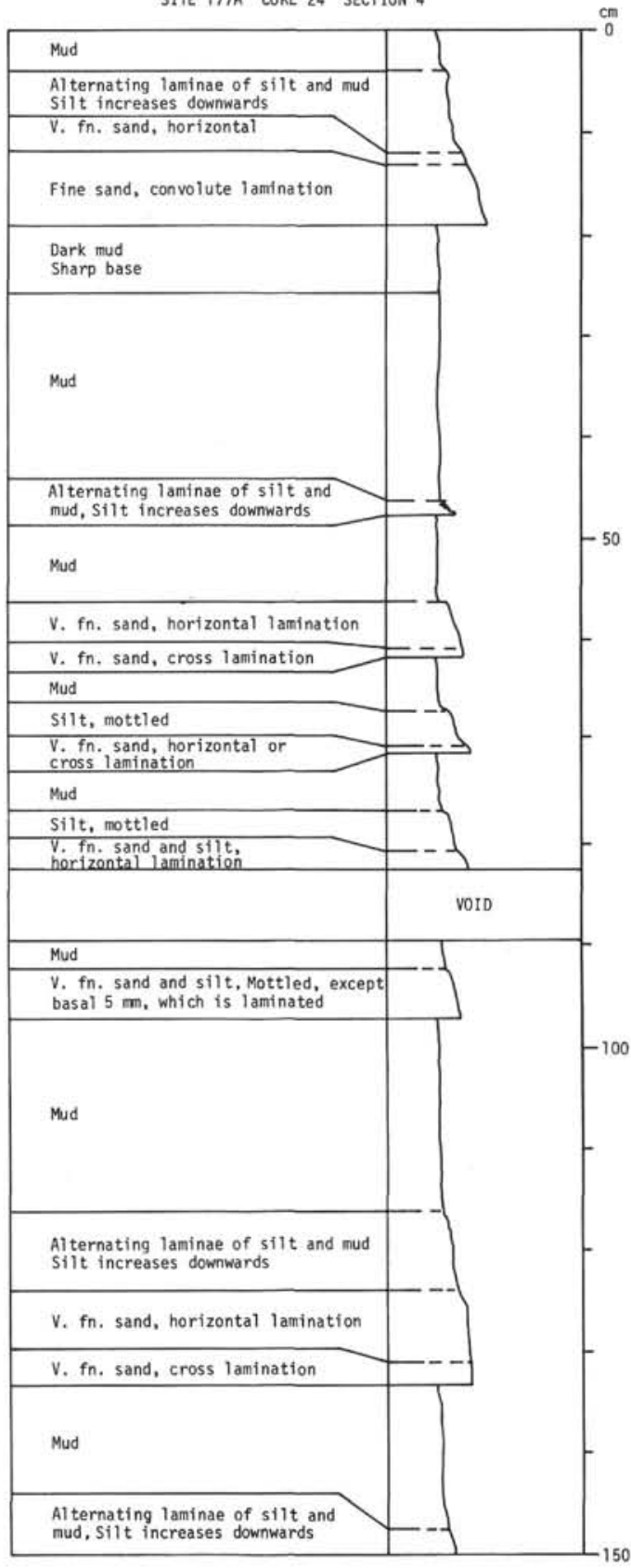

Figure 8. Detailed lithologic descriptions of sections from Hole 177A with partly indurated silt and fine sand beds (for explanation and key, see Figure 2). 


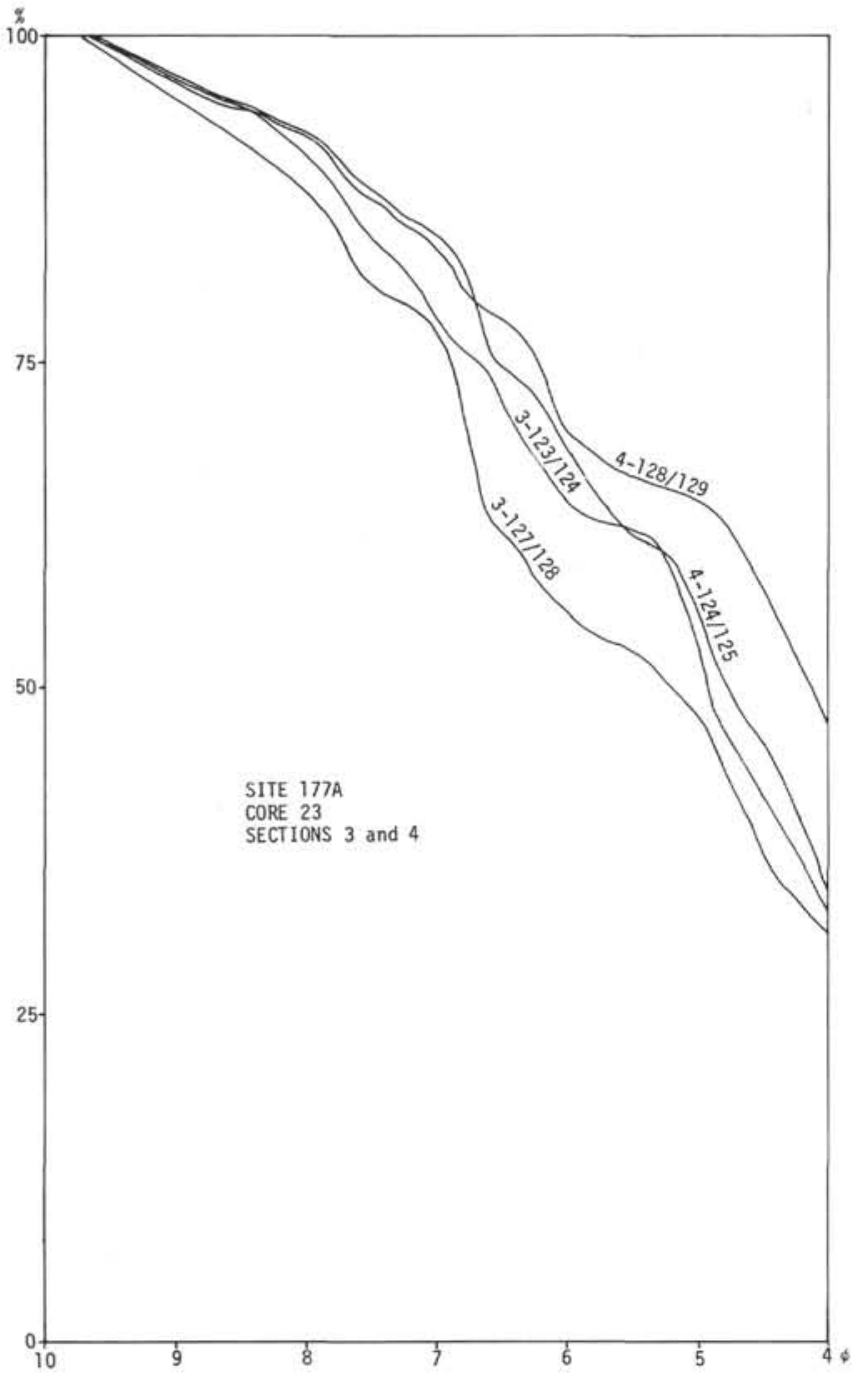

Figure 9. Grain size distribution in partly indurated silts from Hole 177A. Determined by photoextinction sedimentometer.

size in a bed. A decrease in abundance of coarse fraction might also result from gradual exhaustion of a sediment source being winnowed by bottom currents.

There are three features in the Gulf of Alaska sediments described here that make a turbidite origin less attractive:

1) The upward decrease in grain size is less clearly demonstrated.

2) Individual silt laminae are generally sharp based.

3) Diffuse silt laminae occur immediately below the lowest prominent coarse silt (Figure 11c). (This is a common feature seen in a number of lithified rocks).

Nevertheless, the bottom current hypothesis remains unattractive for the following reasons:

1) There is a lack of winnowed biogenous debris in the laminae, even where the interbedded muds are rich in biogenous material.

2) Residual coarse sands and gravels are not found, despite the input of glacial erratics.

3) If a complete bed of grouped silt laminae is deposited by a single waning tidally controlled bottom current,

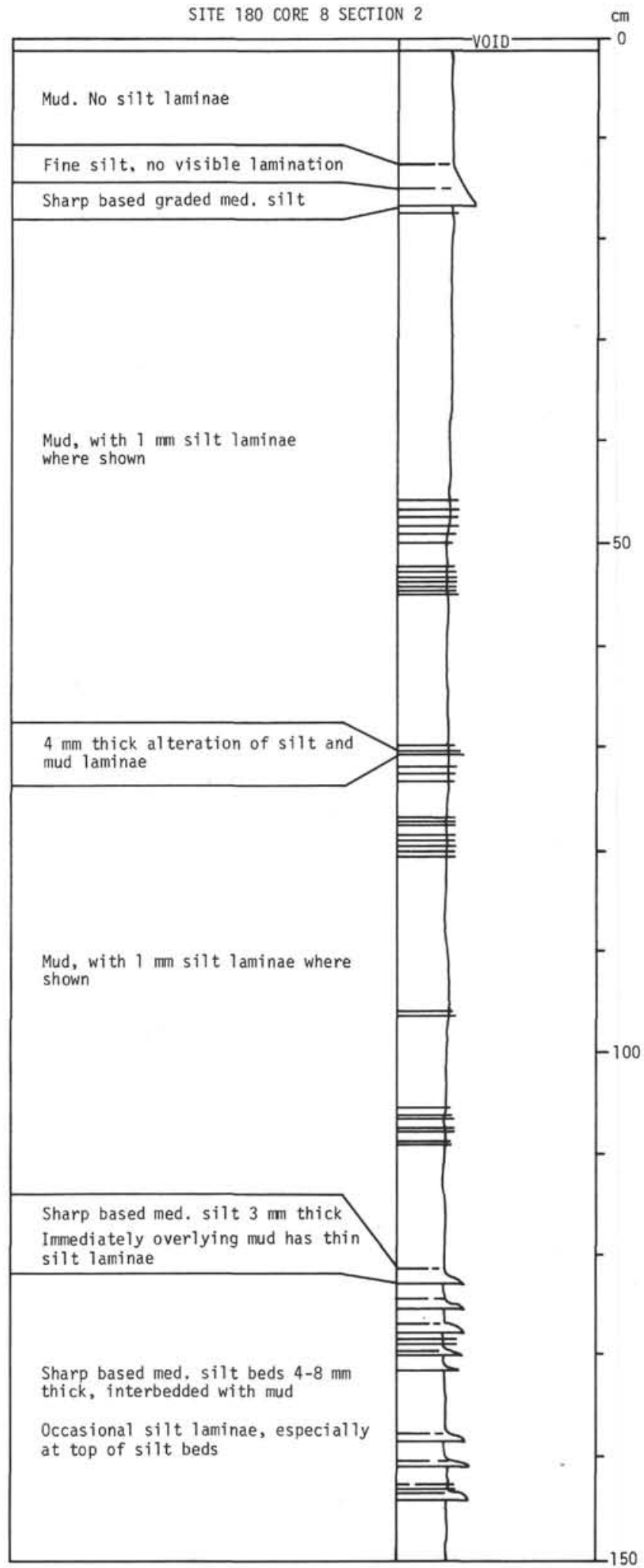

Figure 10. Detailed lithologic description of section with grouped silt laminae (for explanation and key, see Figure 2). 
A

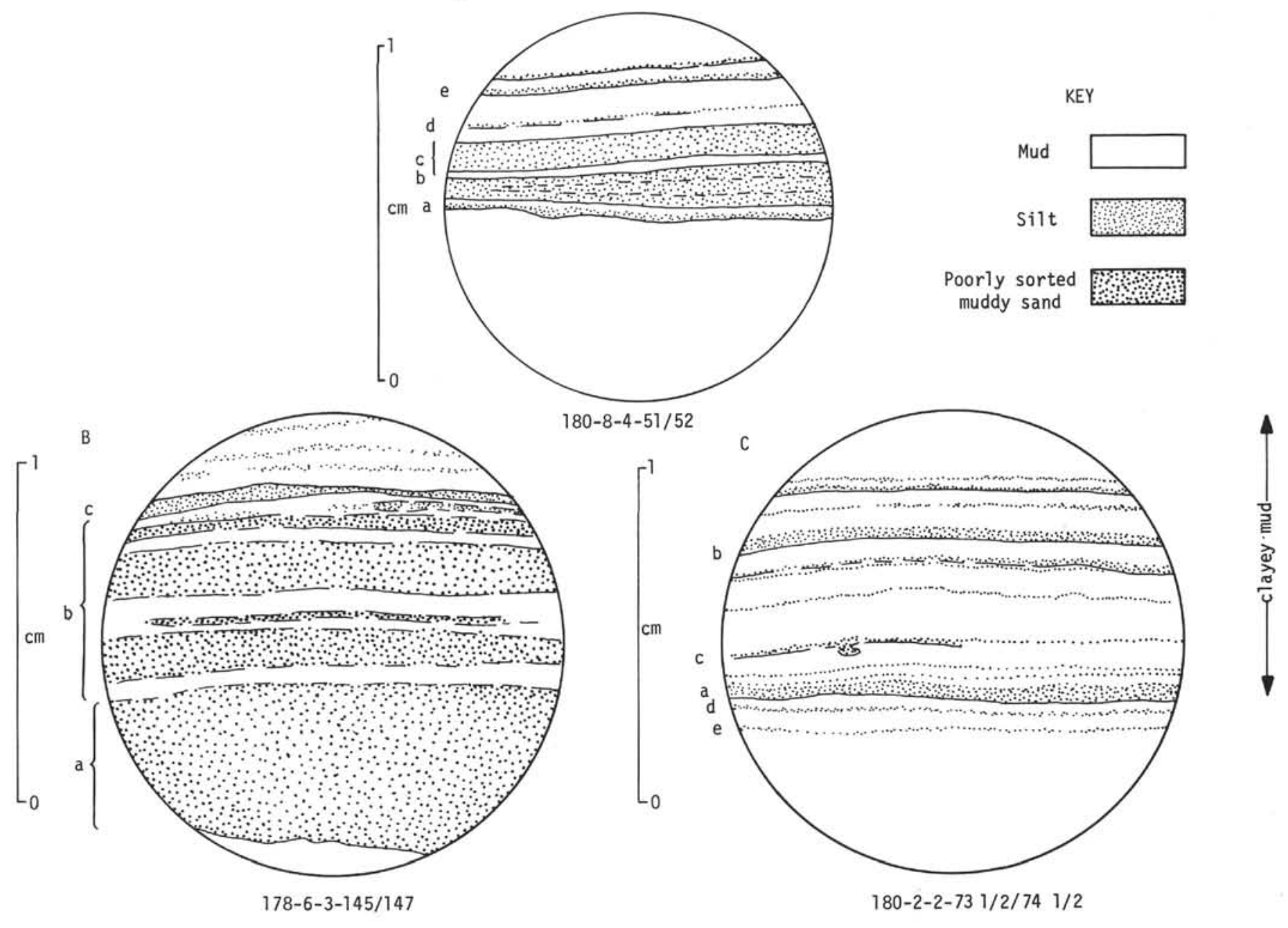

Figure 11. Drawings of thin sections of grouped silt laminae (prepared from projected images). For explanation, see text.

then the amount of sediment transported by the current is very high. If it is deposited by several currents, then it is difficult to account for the size grading.

Not enough is known about the processes of deposition of silt and clay from currents to permit a firm interpretation of the grouped silt laminae at present.

Allen (1970) has proposed a mechanism for the formation of alternating dark and light laminae in fine turbidite sands. He suggests that the darker sand laminae (usually finer and with a higher percentage of clay) result from gradual accretion of finer material separated out by shear sorting at the base of a dispersed quasi-laminar traction carpet. The lighter, coarser sand laminae are due to sudden collapse of the traction carpet by impingement of a turbulent eddy whose velocity of rotation is opposed to the current movement. Internal reverse grading should be produced by the shear sorting process and was found in the sands examined by Allen. In the silts and muds in this study, however, reverse grading is not present, indeed, in some cases, light-colored well-sorted silts have a pronounced normal grading. This suggests that the detail of Allen's hypothesis is not applicable in this case.

\section{Isolated Silt Laminae}

Isolated silt laminae appear to show the same range of thickness, grain size, and sorting as do individual laminae within grouped silt laminae.

They have not been further studied.

\section{DISTINCTION OF TURBIDITE AND PELAGIC MUDS}

\section{Glacial Pelagic Muds}

Sandy muds with granules and pebbles are probably of pelagic origin. Their primary depositional fabric is probably also different from that of turbidites.

Three size analyses (Figure 14) have been made of glacial erratic mud from Site 179 and extreme top of Site 181. In both cases, sediment was deposited on a topographic high, out of the reach of turbidity currents. Pebbles larger than $0.4 \mathrm{~cm}$ in diameter and visible in X-radiographs make up from 0.5 to 1.0 percent of such sediment.

Figure 15 shows a detailed core log of Section 178-25-2 and two series of grain size analyses. Gentle scraping with a spatula shows that the top few centimeters of 30-cm-thick 


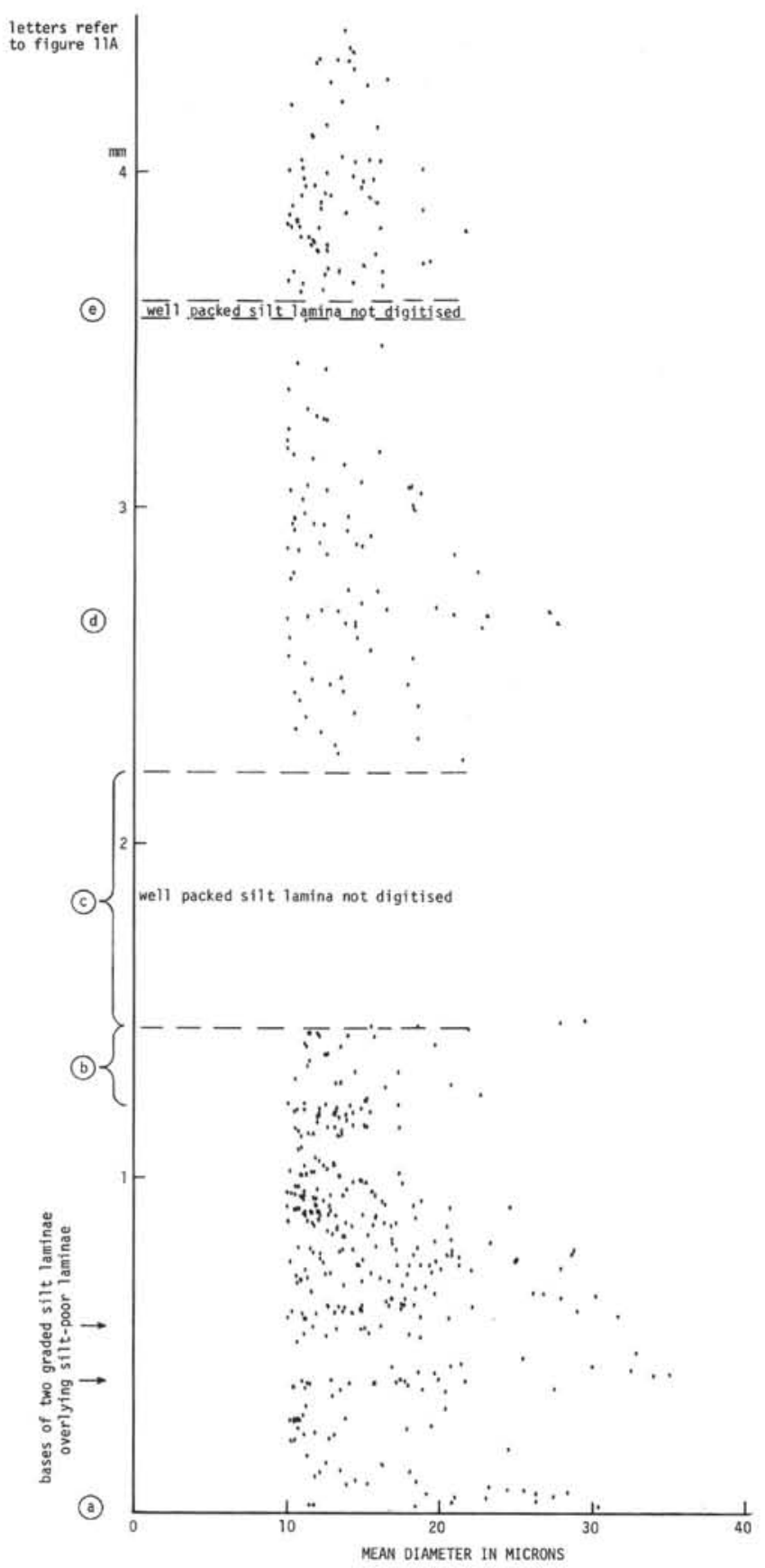

Figure 12. Size of silt grains in a bed of grouped silt laminae (shown in Figure 11a) plotted against height in bed. All grains coarser than $10_{\mu}\left(6.7_{\phi}\right)$ in a $0.5 \mathrm{~mm}$ wide strip of thin section plotted. Distance along $\mathrm{x}$-axis indicates size of silt grains; density of points is an indication of packing or sorting. Letters refer to Figure 11a. For explanation, see text.

mud beds have an unusually high proportion of coarse sand and granules. The beds are clearly bioturbated, and coarse sand is found in the top 7 to $10 \mathrm{~cm}$; below this the muds have a finer median size and are better sorted. These lower muds are probably of turbidite origin. Extrapolation of this results suggests that at least 50 percent, and probably considerably more, of the muds in similar sequences are of turbidite origin.

\section{Hard Fissile Mud}

A common feature of many cores is the occurrence of a harder, fissile, lighter-colored mud overlying a softer, darker mud, which itself overlies turbidite sand or silt.

The alternation of green fissile muds and gray soft muds has been studied in detail in Site 178 Cores 17 to 51 . A typical core is shown in Figure 16. Soft gray (N.4) muds overlie silt laminae and beds. One gray mud has a sharp base of green fissile mud. Fissile, green (5GY4/1) muds overlie the gray muds; the color change is gradational over about $1 \mathrm{~cm}$.

In Cores $178-17$ to 51 , most of the green muds are richer in diatoms than the gray muds, although a few are barren. The upper parts of gray mud beds are finer than the green beds; the lower parts are siltier. Green beds have a higher "sand" content due almost entirely to biogenous material (Figure 17). The gray muds are significantly higher in organic carbon, and rather lower in calcium carbonate than the green muds (Figure 18).

The position of the gray muds relative to silt beds and laminae suggests that they are genetically related. The gray muds are thus probably of turbidite origin, while the interbedding green muds are hemipelagic. Higher organic carbon is a common feature of turbidite muds (Griggs et al., 1969).

However, in some other holes on Leg 18, superficially similar green/gray mud alternations did not have the same simple relationship to silt beds. Color in marine sediments is sufficiently subtle and ephemeral that care should be taken in extrapolating to other sequences the interpretation of the gray muds as turbidite. For example, further south, off the coast of Oregon, turbidite muds tend to be green and non-turbidite muds are more gray (Griggs et al., 1969).

The cause of the greater hardness and fissility of the green biogenous muds is not certain. Rapidly deposited turbidite muds probably have a more open initial floc structure than very slowly accumulating pelagic muds. Alternatively, biogenic silica may partially cement the hard green muds. This question is being further investigated.

The abundance and thickness of gray mud beds again indicate the importance of muds of turbidite origin in the Gulf of Alaska.

\section{INTERPRETATION OF UNIT 3, SITE 181}

Photoextinction sedimentometer determinations of samples from the basal unit of Site 181 are shown in Figure 19c. These, and smear slide examination of silt laminae, show no significant differences from apparently comparable lithologies (muds with silt laminae, and muds rich in erratic debris) found at Sites 178 and 180.

\section{DISCUSSION}

\section{Comparison With Sand Turbidites}

In the introduction, evidence was presented that the deep-water silt beds from the Gulf of Alaska are turbidites. Since most detailed work on turbidites has been concerned 
A

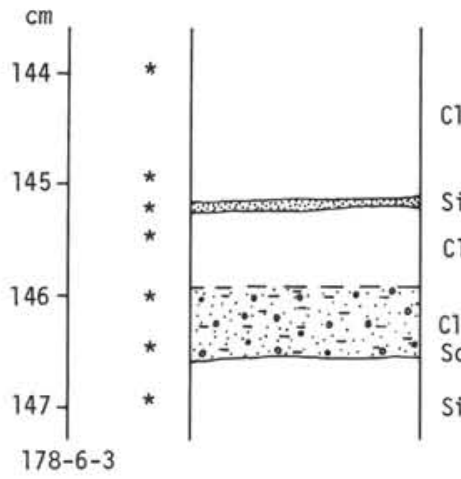

Clayey silt, grades finer upwards.

Silt. 99 percentile $=35 \mu$.

clayey silt.

Clay-rich silt, grades finer upwards.

Some sand grains. 99 percentile $=120 \mu$.

Silty clay.

Well sorted ("clean") silt.

i. Clay rich ("dirty") silt,
often with some sand.

Silty clay and clayey silt.

* Smear slide.

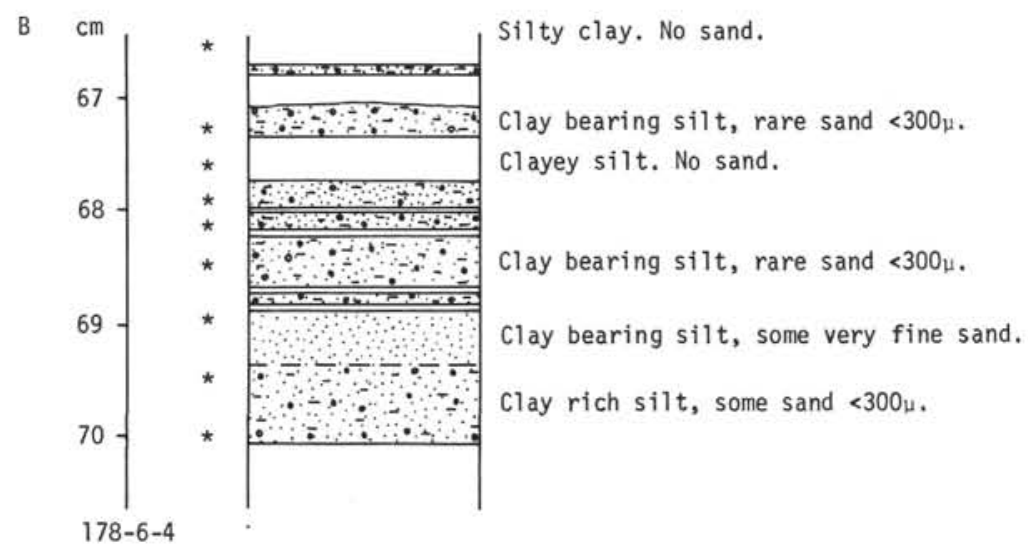

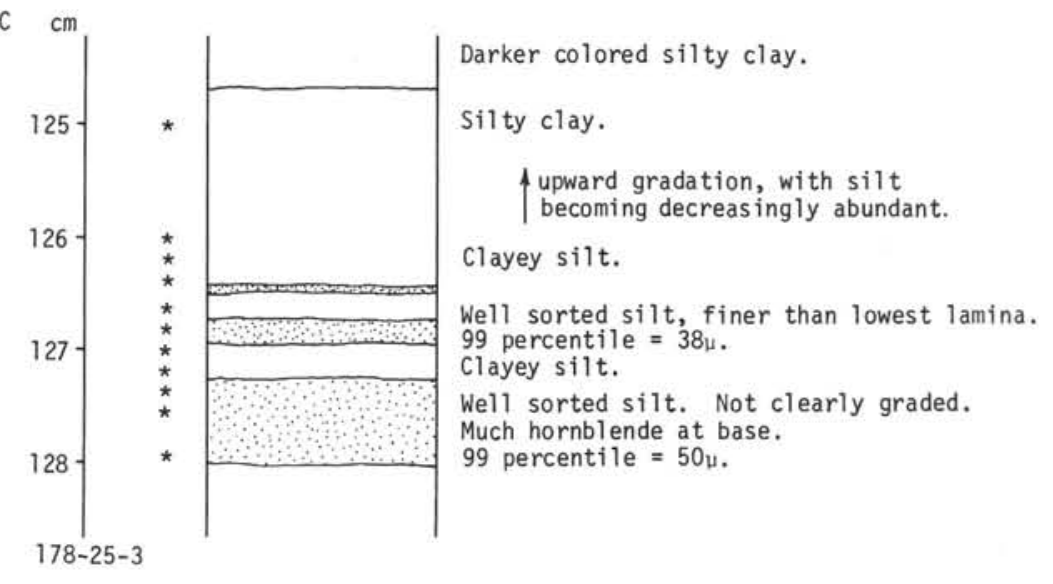

upward gradation, with silt Clayey silt.

than lowest lamina.

ted silt. Not clearly graded.

Much hornblende at base.

$178-25-3$

Figure 13. Sketches of split cores showing grouped silt laminae. Lithologic identification based on smear slides. For explanation, see text.

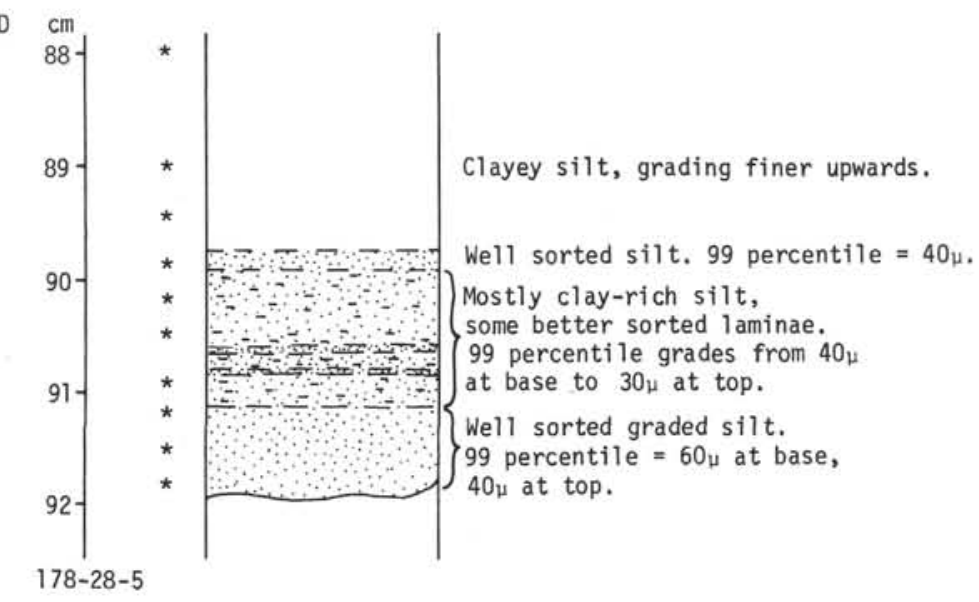




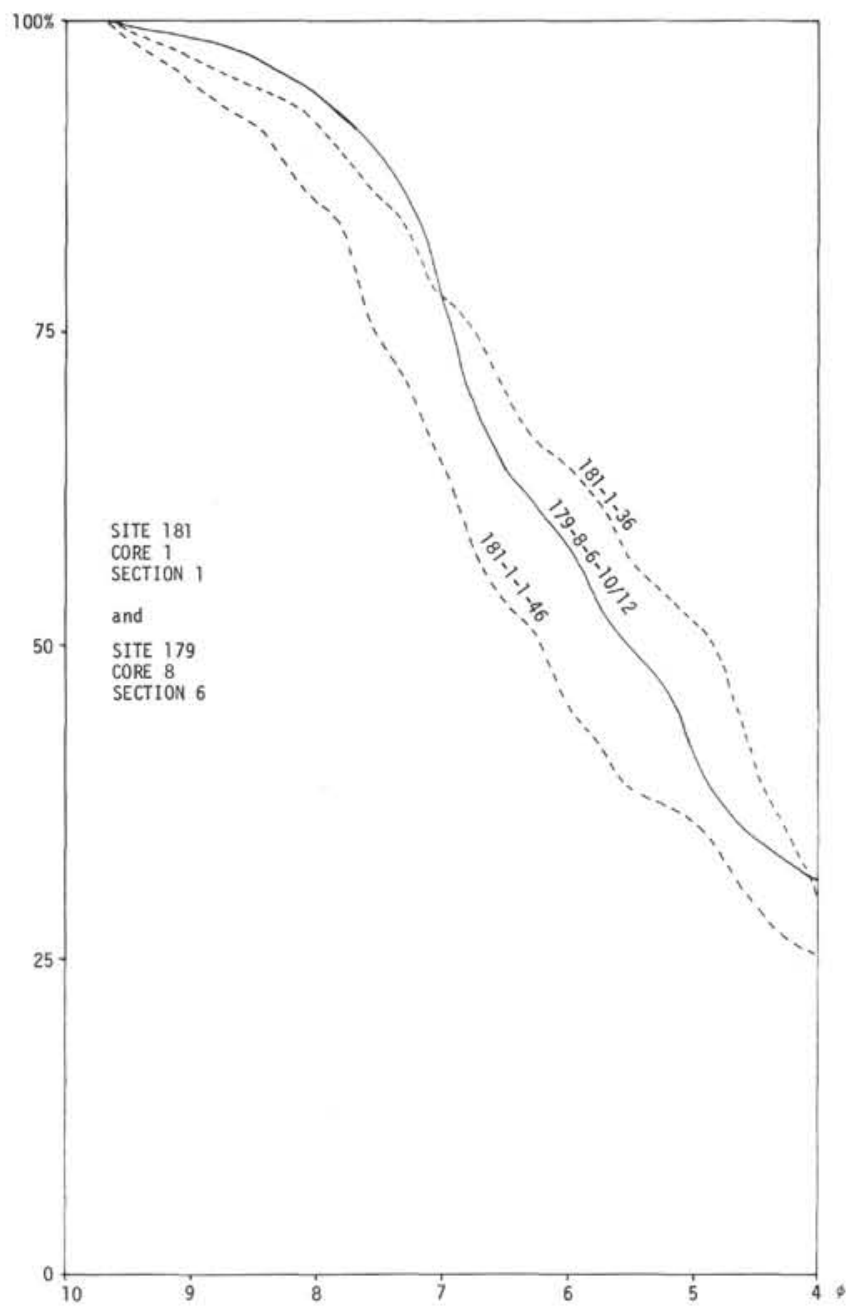

Figure 14. Grain size distribution in glacial erratic muds. Determined by photoextinction sedimentometer.

with sands, it is appropriate to examine how far standard concepts can be applied to silt beds.

The Bouma sequence of sedimentary structures is commonly used in describing sand turbidites. However, structures are rarely visible in the unconsolidated silts described in this paper. Both cross lamination and parallel lamination have been seen, which might correspond to Bouma $C$ and to Bouma $B$ or $D$ divisions respectively.

Experimental flume work on sands allows a dynamic interpretation of the Bouma sequence. The Bouma $B, C$, and probably parts of the $D$ division are deposited from bed load traction under waning power conditions. These deposits can be reproduced in the laboratory (Kuenen, 1966). Rees (1966) experimented in a plane bed (at low velocities), which gave way to ripples, and then again to plane bed as velocity increased. Similar results were obtained by Southard and Harms (1972). Perhaps the Bouma sequence can be extended to silts. The origin of the $A$ division in sand turbidites is less clear; different A divisions are probably of different origins. Most hypotheses do not call for significant bed load traction under steady flow conditions to deposit the $A$ division. Middleton's (1967) experiments imply deposition of an $A$ division associated with unsteady flow near the head of the current, and, at higher sediment concentrations, deposition by "freezing" of a pseudolaminar, dense, fluid-sediment mixture.

A distinction can be made between unsteady and/or high density flow near the head and steady flow with deposition through tractional bed load movement in the tail of a turbidity current. This would be valid for silt turbidity currents, even if a direct comparison of bed forms with sand turbidity currents is not possible. The thick poorly sorted turbidites in the lower part of Site 178 might have originated in this way. Poor sorting, lack of good grading, lack of lamination, and dispersed mud and wood clasts are all features hard to explain by steady tractional bed load deposition. As a corollary, moderately and well-sorted laminated or cross-laminated silts have a mode of deposition comparable to well-sorted, laminated sands in turbidites.

However, the poorly sorted silts overlying well-sorted laminated sands in Hole 177A show that deposition from the head of a turbidity current is not the only way in which poorly sorted silts are deposited. Rapid cohesive deposition of clay, trapping silt-sized particles, may be the dominant process here (Piper, 1972). Indeed, such a process, probably promoted by high concentrations of suspended clay, may be the explanation of all the poorly sorted silts.

\section{The Origin of The Silt}

"Silt occurs primarily as a constituent of shales rather than as siltstone" (Pettijohn, 1957, p. 337). Many of the silts described in this paper are overlain by thick turbidite muds and some are underlain by fine sand. Turbidites generally decrease in maximum size distally.

The well-sorted silts in the 6 to $6.5 \phi$ range in Core 178-39 might also be explained as resulting from sorting within a turbidity current. Alternatively, they were deposited from a turbidity current carrying little else but 6 to $7 \phi$ silt. This could have formed from direct flow into the sea of a glacial outwash stream with a large rock floor suspended load of sufficient density to form a submarine turbidity current. (This process has been postulated for other turbidites by Heezen et al., 1964, and Nesterof et al., 1969). Rees (1966) describes well-sorted silt of median size $6.6 \phi$ from a glacial outwash stream.

\section{ACKNOWLEDGMENTS}

Most of this work was carried out during the tenure of a Research Fellowship from Jesus College, Cambridge, England. I thank Prof. H. B. Whittington for provision of research facilities at the Department of Geology, University of Cambridge.

\section{REFERENCES}

Allen, D. W., 1970. Sedimentary texture - a key to interpreting deep marine dynamics. Ph.D. dissertation, Oregon State University. 167 p.

Folk, R. L., 1966. A review of grain size parameters. Sedimentology. 673 . 

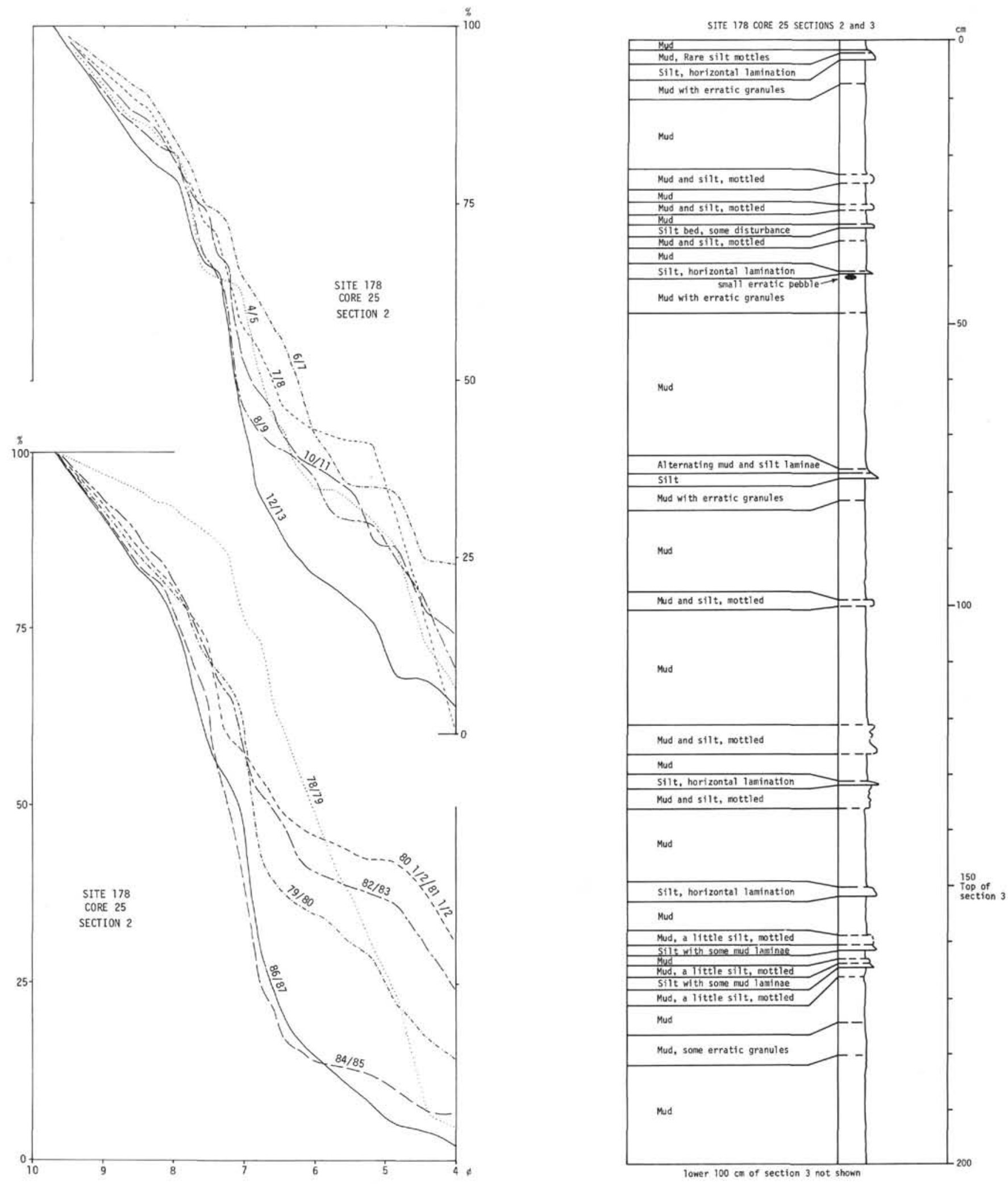

Figure 15. Grain size distribution and detailed lithologic description of slightly bioturbated beds with glacial erratic mud overlying turbidite mud. (Size analyses by photoextinction sedimentometer. For explanation and key to lithologic description, see Figure 2). 


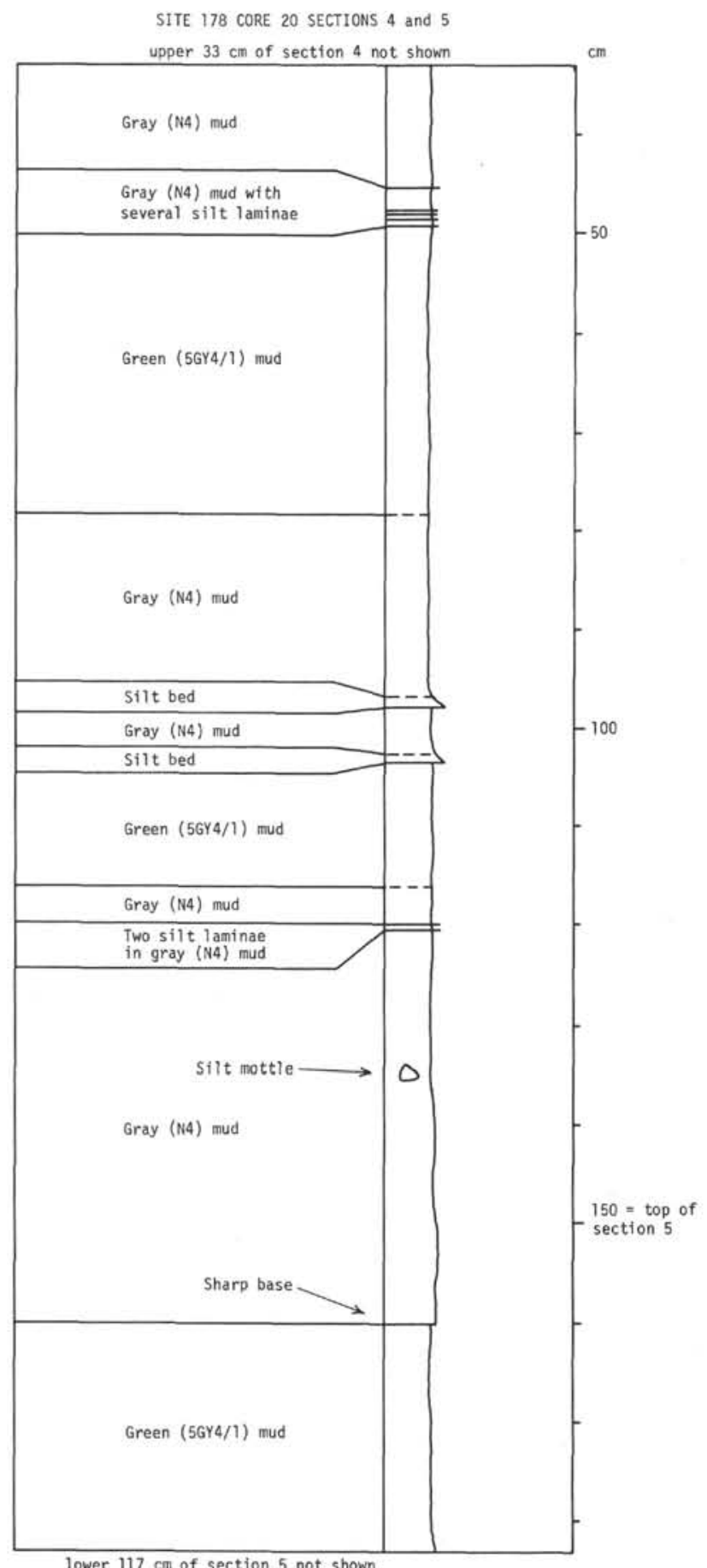

Figure 16. Detailed lithologic description of section showing alternation of hard, fissile, green mud and soft, gray mud. (For explanation and key, see Figure 2).
Griggs, G. B., Carey, A. G., and Kulm, L. D., 1969. Deep sea sedimentation and sediment - fauna interaction in Cascadia Channel and on Cascadia Abyssal Plain. DeepSea Research. 16, 157.

Heezen, B. C., Menzies, R. J., Schneider, E. D., Dwing, W. M., and Granelli, N.C.L., 1964. Congo submarine canyon. Bull. Am. Assoc. Petrol. Geologists. 48, 1126.

Jordan, C. F., Fryer, G. E., and Hemmen, E. H., 1971. Size analysis of silt and clay by hydrophotometer. J. Sed. Petrology. 41, 489.

Kuenen, Ph. H., 1966. Experimental turbidite lamination in a circular flume. J. Geology. 74, 523.

Middleton, G. V., 1967. Experiments on density and turbidity currents. III. Deposition of sediment. Canadian J. Earth. Sci. 4, 475.

Nesterof, W., Duplaix, S., Sauvage, J., Lancelot, Y., Melieres, F. and Vincent, E., 1969. Les dépots recents du canyon de Cap-Breton. Bull. Soc. Geol. Fr. (7), 10, 218.

Partheniades, E. and Paaswell, R. E., 1968. Erosion of cohesive soil and channel stabilization. Civil Engineering Report, 19, State University of New York, Buffalo. $119 \mathrm{p}$.

Pettijohn, F. J., 1957. Sedimentary rocks. 2nd ed. New York (Harper and Bros.). $718 \mathrm{p}$.

Piper, D. J. W., 1972. Turbidite origin of some laminated mudstones. Geol. Mag. 109.

Rees, A. I., 1966. Some flume experiments with a fine silt. Sedimentology. 6, 209.

Shepard, F. P. and Marshall, N. F., 1969. Currents in La Jolla and Scripps submarine canyons. Science. 165, 177.

Simmons, G., 1959. The photoextinction method for the measurement of silt-sized particles. J. Sed. Petrology. 29, 233.

Southard, J. B. and Harms, J. C., 1972. Sequence of bedforms and stratification in silts based on flume experiments (Abstract). Bull. Am. Assoc. Petrol. Geologists. 56, 654 . 


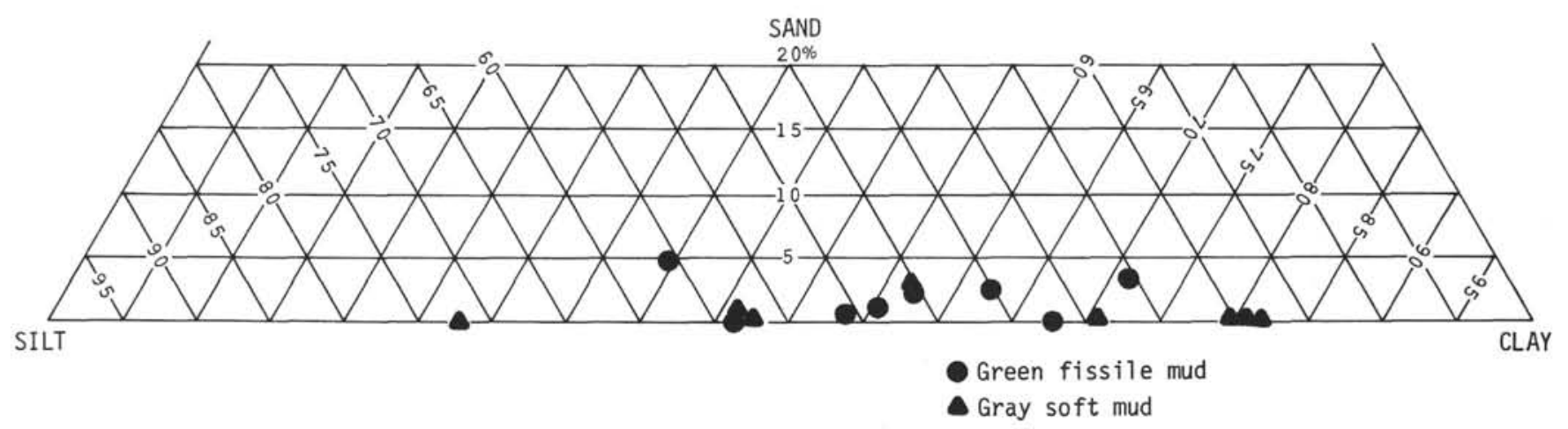

Figure 17. Grain size analysis of pairs of samples of hard, fissile, green mud and soft, gray mud, Site 178, Cores 17 to 51 (Each pair comes from the same section of core. Size analyses by DSDP using wet sieving and pipette).

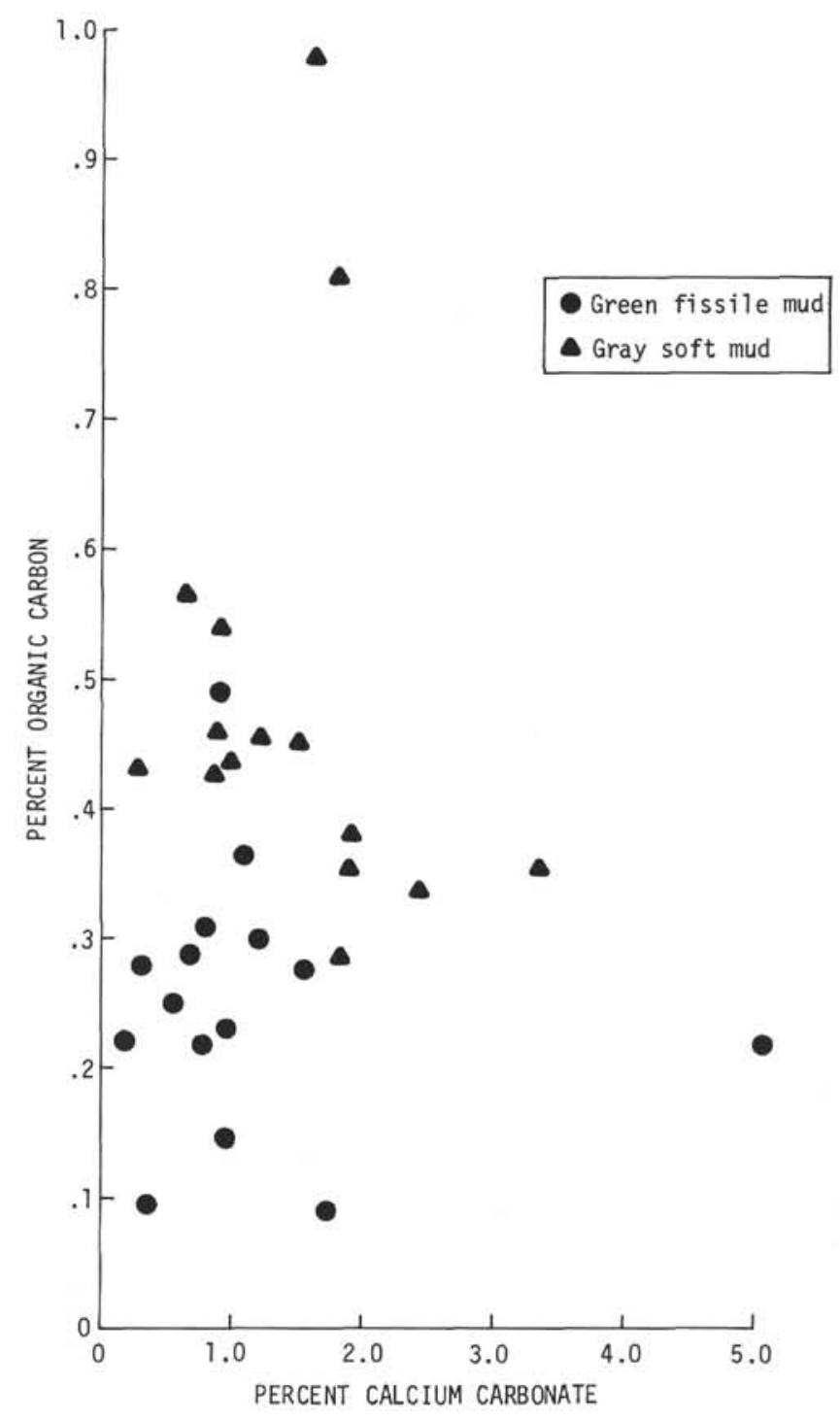

Figure 18. Organic carbon and calcium carbonate composition of pairs of samples of hard, fissile, green mud and soft gray mud, Site 178, Cores 17 to 51 . (Each pair comes from the same section of core. Analyses by DSDP). 


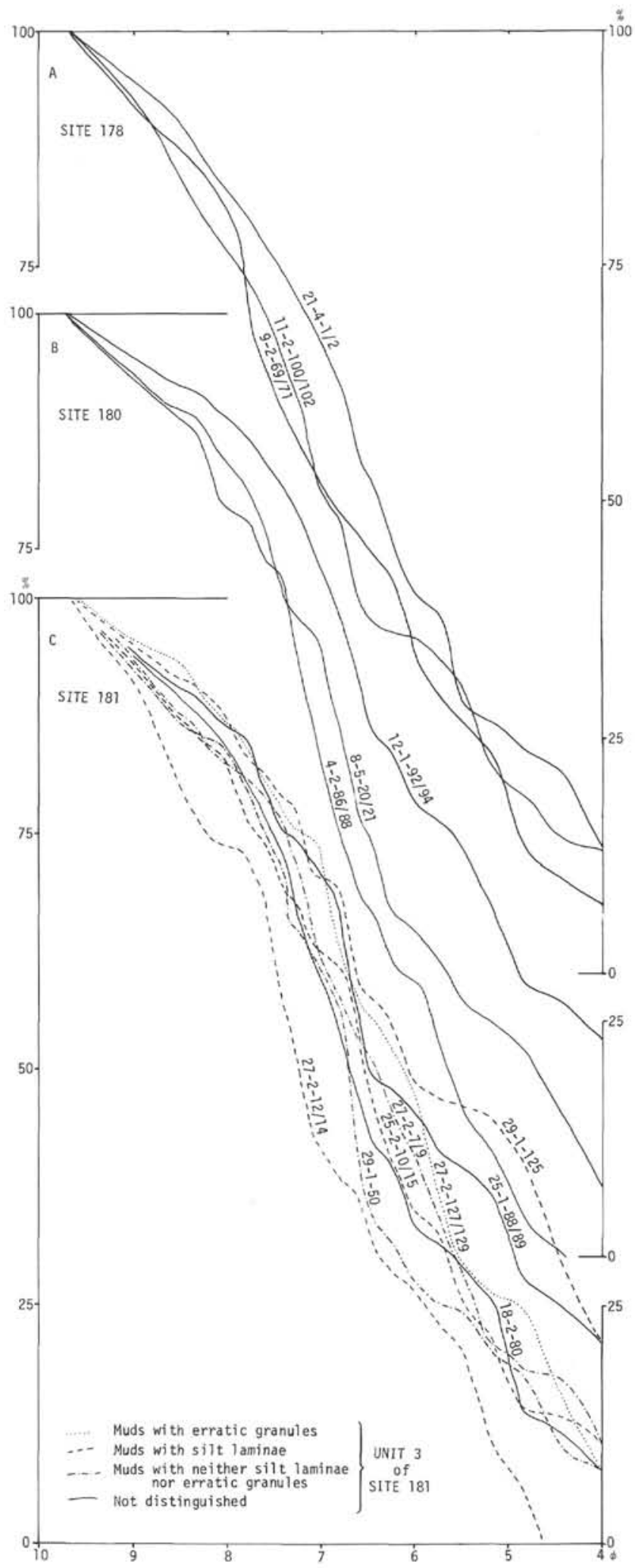

Figure 19. Grain size distribution in muds from Sites 178 , 180 and 181. Determined by photoextinction sedimentometer. 


\section{PLATE 1}

Figure 1 178-17-2(132-143). Carbonate-cemented silt bed with cross lamination overlain by horizontal lamination. Mud both above and below silt bed.

Figure 2 178-48-1(126-134). Carbonate-cemented sandy silt bed, with dispersed mud and wood clasts.

Figure 3 177A-23-5(0-10). Horizontally laminated poorly sorted silt. X-radiograph.

Figure 4 177A-23-2(111-118). Horizontally laminated poorly sorted silt. X-radiograph.

Figure 5 177A-23-4(104-115). Horizontally laminated poorly sorted silt. X-radiograph. 
PLATE 1
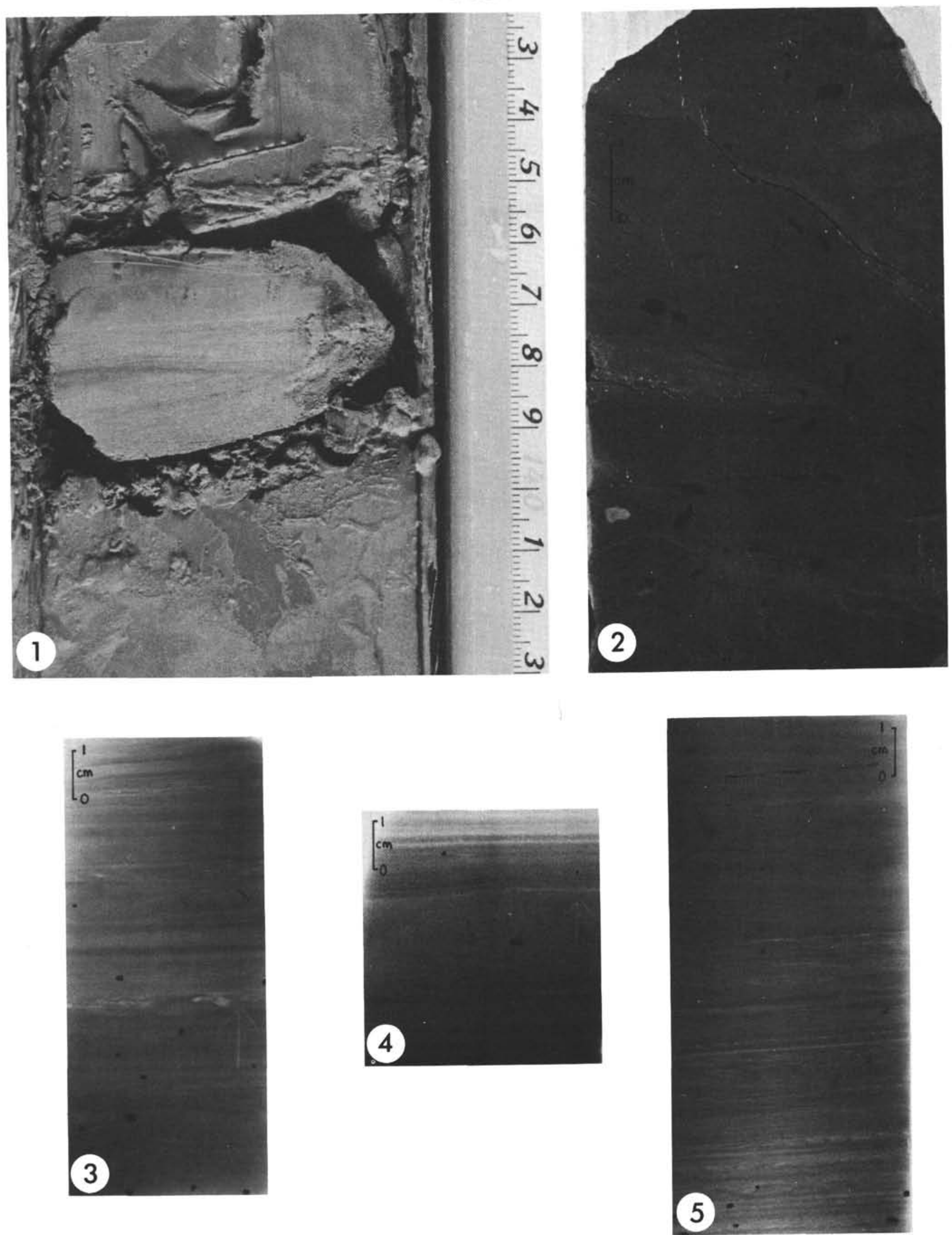